\title{
Caixa, BB e BNDES Notas sobre sua evolução patrimonial recente *
}

\author{
Andrej Slivnik ** \\ Fernanda Feil ${ }^{* * * * * * * *}$
}

\section{Resumo}

Este artigo tem como objetivo avaliar as estratégias de atuação da Caixa Econômica Federal, do Banco do Brasil e do BNDES entre os anos 2000 e 2015, por meio da análise da evolução de suas posições patrimoniais. Para tanto, foram utilizados os dados disponibilizados no Banco Central do Brasil - com destaque para a série Balancetes, mais detalhada do que as usualmente discutidas em estudos sobre o tema - bem como em seus respectivos relatórios de administração. Acredita-se que a análise das posições patrimoniais destas três instituições, em maior detalhamento, contribui para esclarecer seus diferentes padrões de atuação. O artigo organiza-se em quatro seções, além da introdução e da conclusão. Na primeira, discute-se a dinâmica das operações de crédito dos bancos públicos federais, identificando fases distintas e destacando seu papel contracíclico no auge da crise financeira internacional. Nas seções seguintes, são analisadas as posições ativas e passivas das três instituições, individualmente, atentando para estratégias de alocação dos ativos e de atuação nos diversos nichos do mercado creditício e para as fontes de recursos, sobretudo públicos, utilizadas para sustentar a expansão observada em suas operações de crédito. O estudo identifica a centralidade das estratégias de diversificação das três instituições no mercado de crédito, ainda que tenham permanecido fortes em seus respectivos nichos, acompanhada de diversificação nas fontes de recursos.

Palavras-chave: Caixa Econômica Federal; Banco do Brasil; BNDES; Bancos Públicos; Bancos de Desenvolvimento.

\section{Abstract \\ Caixa, BB and the BNDES - An analysis of balance sheet evolution}

The purpose of this article is to evaluate the strategies of Caixa Econômica Federal, Banco do Brasil and the BNDES, by analyzing the development of their equity positions, between 2000 and 2015 . The article uses data collected by the Brazilian Central Bank- in particular the series of Balancetes, which are more detailed than those usually discussed in studies on the subject - as well as in their respective management reports. It is believed that the analysis of the equity positions of these three institutions, in greater detail, contributes to clarifying their different performance patterns. The article is organized into four sections, in addition to the introduction and conclusion. In the first section, we discuss the dynamics of credit operations of federal State-owned banks, identifying distinct phases and highlighting their countercyclical role in the heyday of the international financial crisis. In the following sections, the active and passive positions of the three institutions are analyzed individually. Focus is given to the strategies for asset allocation and performance in the various credit market niches, as well as the sources of funding, mainly public, used to support the expansion observed in their credit operations. The study identifies the centrality

\footnotetext{
* Artigo recebido em 30 de junho de 2017 e aprovado em 24 de março de 2018.

** Doutorando em História - Instituto de Filosofia e Ciências Humanas da Universidade Estadual de Campinas (IFCH/Unicamp), Campinas, SP, Brasil. E-mail: sli.andrej@gmail.com.

*** Doutoranda em Economia pela Universidade Federal Fluminense (UFF), Niteroi, RJ, Brasil. E-mail: nandafeil@yahoo.com.

${ }^{* * * * *}$ Bolsista da Fundação de Amparo à Pesquisa do Estado do Rio de Janeiro (Faperj 10), Rio de Janeiro, RJ, Brasil.
} 
Andrej Slivnik, Fernanda Feil

of the diversification strategies of the three institutions in the credit market. They have remained secure in their respective niches, accompanied by diversification in the origins of their funding.

Keywords: Caixa Econômica Federal; Banco do Brasil; BNDES; State-owned Banks; Development banks. JEL E02, E44, G2, O1.

\section{Introdução}

Entre o contágio da crise financeira internacional sobre a economia brasileira, em junho de 2008, e o encerramento de 2015, as operações de crédito das cinco instituições financeiras públicas federais ${ }^{1}$ registrou crescimento de $243 \%$, em termos reais. A oferta de crédito dos bancos públicos federais (BPFs), que representava 33,9\% do total das operações do Sistema Financeiro Nacional (SFN) em junho de 2008, atingiu participação de 53,1\% em dezembro de 2015. As razões que viabilizaram tal ultrapassagem ainda são pouco discutidas, especialmente no que diz respeito ao detalhamento das estratégias adotadas nesta conjuntura.

O presente trabalho tem como objetivo avaliar a atuação da Caixa Econômica Federal (Caixa), do Banco do Brasil (BB) e do Banco Nacional de Desenvolvimento Econômico e Social (BNDES), no período entre 2000 e 2015, por meio da análise da evolução de seus respectivos balanços patrimoniais. O foco sobre estas três instituições se justifica, primeiramente, por serem os maiores Bancos Públicos (BPs) brasileiros em termos de ativos e, além disso, pela atuação comercial das duas primeiras instituições, características que fazem de ambas concorrentes diretas dos outros três grandes agentes do mercado de crédito brasileiro - Itaú, Bradesco e Santander. No caso da terceira, o interesse reflete sua importância enquanto agente de desenvolvimento e instituição financeira de segundo piso, repassadora de recursos de longo prazo para todo o SFN.

O recuo na periodização ao ano 2000 tem como objetivo avaliar a evolução destas três instituições na esteira das reformas implementadas no SFN, em particular o Programa de Fortalecimento das Instituições Financeiras Federais - Proef. No entanto, devido às especificidades e à atuação errática dos BPFs, durante este primeiro período, as análises comparativas serão aprofundadas para os anos entre 2003 e 2015.

O trabalho foi dividido em quatro seções, além desta introdução e da conclusão. $\mathrm{Na}$ primeira seção, "Bancos públicos e privados na esteira da crise financeira internacional", realiza-se uma comparação entre as operações de crédito dos Bancos Públicos Federais vis-àvis o restante do SFN, de modo a identificar diferentes padrões de atuação. Além disso, a seção explora os variados comportamentos apresentados pelos BPFs, nas fases que se sucederam neste período, mostrando as distintas estratégias adotadas, diante dos desafios apresentados em cada conjuntura. As três seções seguintes, a saber, "Caixa Econômica Federal", "Banco do Brasil" e "Banco Nacional de Desenvolvimento Econômico e Social", exploram mais detalhadamente os dados patrimoniais dessas instituições, com destaque para o perfil de

(1) Este trabalho tem como objeto a atuação recente do Banco do Brasil, da Caixa e do BNDES. No entanto, cabe notar que o grupo dos bancos públicos federais inclui também o Banco do Nordeste do Brasil - BNB e o Banco da Amazônia. 
composição de suas contas ativas e passivas, inclusive desdobrando os dados agregados das operações de crédito e de repasses.

\section{Bancos públicos e privados na esteira da crise financeira internacional}

Nas últimas décadas, o sistema financeiro nacional se caracterizou pela crescente participação das instituições financeiras públicas em seu total de ativos, notadamente pelo aumento da presença destes agentes no mercado de crédito. Depois da retração verificada como resultado dos programas de reestruturação do SFN, na década de 1990, a crise internacional iniciada em 2007-2008 ensejou as condições necessárias para a reativação do crédito público por meio de sua atuação contracíclica. O movimento de ampliação na participação dos Bancos Públicos Federias, observado ao longo deste período, guarda diferenças que podem ser melhor explicitadas dividindo-o em sete fases distintas, conforme explicitado no Gráfico 1 - que compara a taxa de crescimento da economia, medida pelo PIB anual, com o crescimento das operações de crédito dos BPFs e das demais instituições do SFN.

\section{Gráfico 1}

Variação real do Saldo de Operações de crédito e do Produto Interno Bruto - PIB

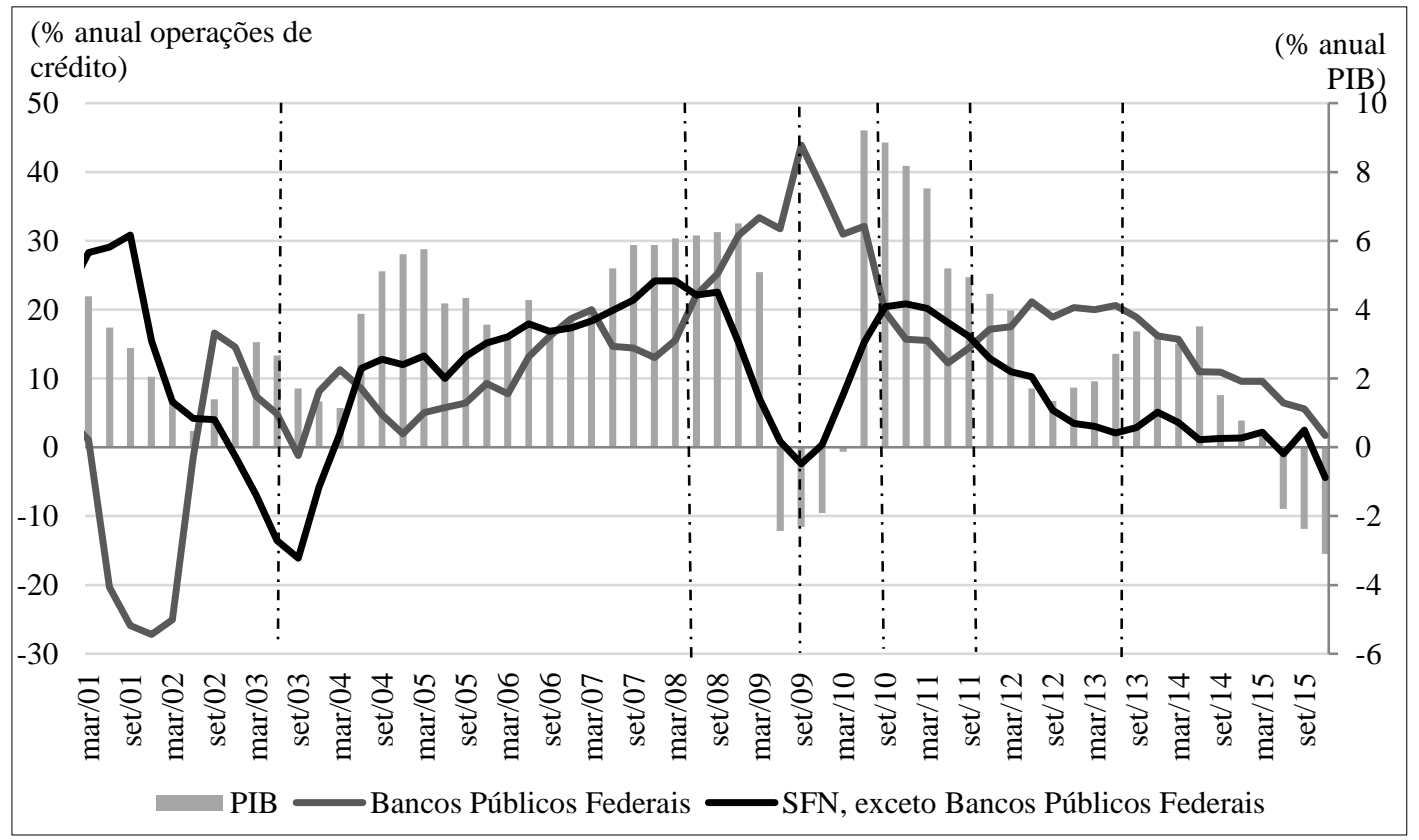

Fonte: BCB e IBGE. Dados inflacionados pelo IPCA, para valores de dezembro de 2015.

A primeira fase (jan./2000 a jun./2003) corresponde ao movimento final de equacionamento dos ativos dos BPFs, ainda resquício das reformas orientadas do sistema 
financeiro nacional ${ }^{2}$. Além de terem sido usados para carregar títulos da dívida pública, tinham como missão prover o Tesouro Nacional com pagamento de dividendos (Nogueira da Costa, 2015). O período apresenta taxas de variação erráticas para as operações de crédito dos BPFs, acompanhado de queda acentuada do restante do SFN. Como será verificado melhor na próxima seção, o recuo das operações de crédito dos BPFs reflete, principalmente, a cessão de parte da carteira de Crédito da Caixa para a Empresa Gestora de Ativos (Emgea ${ }^{3}$ ), nos marcos de seu programa de saneamento. De todo modo, observa-se que não há relação significativa entre a taxa de crescimento do PIB e a variação real das operações de crédito, o que se explica pelo momento complicado da economia nacional e pelo fato de o crédito total como porcentagem do PIB ser ainda muito baixo no país (24,3\%, em junho de 2003).

Tabela 1

Taxas médias de crescimento trimestral real das operações de crédito (\%)*

\begin{tabular}{l|c|c|c|c|c|c|c}
\hline & $\begin{array}{c}\text { Mar.2000/ } \\
\text { jun2003 }\end{array}$ & $\begin{array}{c}\text { Set.2003/ } \\
\text { jun2008 }\end{array}$ & $\begin{array}{c}\text { Jun.2008/ } \\
\text { set2009 }\end{array}$ & $\begin{array}{c}\text { Set.2009/ } \\
\text { set2010 }\end{array}$ & $\begin{array}{c}\text { Dez.2010/ } \\
\text { set2011 }\end{array}$ & $\begin{array}{c}\text { Dez.2011/ } \\
\text { jun2013 }\end{array}$ & $\begin{array}{c}\text { Set.2013/ } \\
\text { dez2015 }\end{array}$ \\
\hline BNDES & 2,3 & 1,1 & 8,8 & 7,0 & 1,8 & 3,5 & 2,3 \\
\hline Banco do Brasil & 3,0 & 4,2 & 7,4 & 5,4 & 2,8 & 3,7 & 1,3 \\
\hline Caixa & $-7,3$ & 3,6 & 10,0 & 9,3 & 7,2 & 7,9 & 3,4 \\
\hline Bancos Públicos Federais & $-0,8$ & 3,0 & 8,3 & 6,7 & 3,7 & 4,8 & 2,3 \\
\hline SFN, exceto BPF & $-2,8$ & 3,8 & 1,2 & 4,4 & 4,5 & 1,5 & 0,2 \\
\hline SFN & 0,4 & 3,5 & 3,9 & 5,3 & 4,2 & 3,0 & 1,2 \\
\hline
\end{tabular}

Fonte: 50 maiores e IF.data. BCB.

*Dados inflacionados pelo IPCA, para valores de dezembro de 2015.

A segunda fase (set./2003 a jun./2008) antecede a crise financeira internacional e é caracterizada pelo incremento concomitante das operações de crédito dos BPFs e do restante do SFN, calcada na política de expansão do crédito implantada no governo Luiz Inácio Lula da Silva. No período, a redução da inflação, aliada à diminuição do patamar da taxa de juros, ao crescimento da economia e a avanços no ambiente regulatório - crédito consignado, lei de falência, Sistema de Informações de Crédito - permitiram a ampliação da oferta de crédito (Feil, 2014). Em setembro de 2003, após quase uma década de retração, a participação do crédito do SFN no PIB atingiu seu mínimo histórico $(24,2 \%)^{4}$. A partir de então, registrou altas consecutivas, até alcançar 34,7\% em junho de 2008, às vésperas do efeito-contágio da crise

(2) O processo de reestruturação das instituições financeiras federais ocorreu por meio do Programa de Fortalecimento das Instituições Financeiras Federais (Proef), criado pela Medida Provisória n. 2.155, de 22/06/2001.

(3) Empresa não financeira vinculada ao Ministério da Fazenda para gerir esses créditos, criada no âmbito do Programa de Fortalecimento das Instituições Financeiras Federais (Proef) para gerir créditos problemáticos das instituições financeiras.

(4) A série histórica utilizada se refere aos dados de balanço das instituições financeiras, disponibilizados trimestralmente pelo BCB. Entre dezembro de 1996 e dezembro de 2014, foram utilizados os dados da série "50 maiores bancos", a partir de quando o BCB passou a disponibilizar as informações de balanço por meio da série "IF.data - Dados selecionados de Entidades Supervisionadas". 
internacional sobre a economia brasileira. Ressalta-se que essa alta não teve como vetor dinâmico os BPFs, cuja taxa de crescimento real do crédito foi inferior à do restante do SFN, na maior parte do período - 75,4\% para os primeiros, contra $108,6 \%$ para os últimos (ver Tabela 1). Ou seja, o período apresentou um aumento das operações de crédito, puxado pelos bancos privados, que se utilizaram das mudanças normativas atraindo novos empréstimos que até então não lhes eram permitidos (consignado, por exemplo), e concentrado nos recursos livres, especialmente crédito para consumo (Mora, 2015; Prates; Biancareli).Vale ainda destacar que apesar do relativo sucesso dos bancos privados em aumentar a oferta de crédito, os BPFs tiveram importante papel no crédito segmentado (Araujo; Cintra, 2014), aspecto que será acentuado nas próximas fases.

Apesar do aumento da oferta de crédito, ocorrida na segunda fase, o Brasil ainda apresentava uma baixa relação entre operações de crédito e PIB, em comparação a níveis internacionais (Mora, 2015). Portanto, a partir de meados de 2008, quando os efeitos da crise financeira se fizeram sentir mais decididamente, o que marca o início da terceira fase, havia espaço para ações mais contundentes por parte do governo no sentido de manter a liquidez no mercado. Assim, ainda que a crise tenha impactado o mercado de crédito, houve crescimento real de $20,2 \%$ no total das operações, entre junho de 2008 e setembro de 2009 , o que dissimulou a gravidade do efeito contágio.

Ao lado de políticas macroeconômicas variadas de combate aos efeitos imediatos da crise, tais quais a manutenção dos investimentos públicos, a utilização de incentivos fiscais e a redução da taxa Selic ${ }^{5}$, o governo brasileiro, por meio do Banco Central, liberou os recolhimentos compulsórios e injetou 3,3\% do Produto Interno Bruto - PIB em liquidez no mercado bancário (Barbosa; Souza, 2010; Brasil, 2009) com o objetivo de sustentar a oferta de crédito. No entanto, as incertezas quanto aos desdobramentos da crise aumentaram a aversão ao risco dos bancos comerciais privados, que aplicaram os recursos liberados no compulsório em operações compromissadas com a própria Autoridade Monetária. Diante do "empoçamento" de liquidez nas instituições privadas, o governo recorreu aos BPFs para garantir a sustentação da oferta de crédito $^{6}$, abrindo nova fase no desenvolvimento do SFN, que passou a observar crescente participação do setor bancário público.

Entre o contágio da crise financeira internacional sobre a economia brasileira, em junho de 2008, e dezembro de 2015, a participação dos BPFs nas operações de crédito do SFN cresceu de $22,9 \%$ para $53,1 \%$. A Caixa e o BNDES foram os que apresentaram as maiores taxas de crescimento real $^{7}$ para o período - $569,1 \%$ e $200,0 \%$, respectivamente - seguidas pelo

(5) Num primeiro momento, entre março e setembro de 2008, a taxa Selic sofreu repetidas majorações, saindo de 11,25\% para $13,75 \%$. A partir de dezembro de 2008, passou por sucessivas reduções, atingindo o patamar de $8,75 \%$, em julho de 2009 , onde permaneceu até o princípio de 2010.

(6) O governo editou a MP n. 443, em 2008, que permitiu que os bancos públicos comprassem instituições financeiras privadas, permitindo, no momento de crise, maior resiliência ao SFN (Camargo, 2009)

(7) Para cálculo da taxa de crescimento real, os dados foram inflacionados a valores de dezembro de 2015, pelo Índice de Preços ao Consumidor Amplo - IPCA. 
BB, cujas operações tiveram aumento real de $152,5 \%$. Para que se possa compreender a magnitude da expansão da Caixa, cabe notar que dos 19,2 p.p. de incremento da participação total dos Bancos Públicos Federais nas operações de crédito do SFN, sua contribuição individual foi de 13,4 p.p.

Ao mesmo tempo, ocorreu expressiva elevação do crédito com recursos direcionados. As operações do BNDES permitiram o refinanciamento de dívidas, minimizando maiores altas nas taxas de inadimplência, além de contribuir para estimular setores relevantes e minorar a retração da atividade econômica. O BNDES, o BB e a Caixa direcionaram esforços para financiar, respectivamente, o investimento privado, o setor agrícola e o habitacional. Portanto, os BPFs participaram da estratégia do governo central para frear os efeitos da crise. Como nota Camargo, o momento foi de recuperação do papel destas instituições no fomento ao desenvolvimento, com atuação em setores de menor interesse para as instituições privadas, como o segmento imobiliário, setor agrícola e financiamento de longo prazo (Camargo, 2009, p. 9).

A Tabela 1 mostra que o componente dinâmico do mercado foi a atuação dos BPFs, que apresentaram menor preferência pela liquidez - característica da ação anticíclica implantada pelos controladores e adotada pelos BPFs. Neste contexto de atuação contracíclica, o dinamismo dos BPFs foi essencial para a manutenção do nível de crédito (Oliveira, 2015), contribuindo para a recuperação da atividade.

A quarta fase (dezembro de 2009 e setembro de 2010) iniciou-se com a percepção de que o pior momento do impacto da crise já havia passado, quando a taxa de crescimento do produto voltou a crescer. Os agentes recuperaram as expectativas positivas com reflexos na taxa de investimento. A consequência foi queda na preferência pela liquidez por parte dos bancos privados, levando a uma recuperação da oferta de crédito desses agentes. Em contrapartida, ocorreu desaceleração da oferta de crédito dos BPFs. Note que apesar da desaceleração, os BPFs seguiram com taxas de crescimento maiores do que os privados (ver Tabela 1).

Na quinta fase (dezembro de 2010 e setembro de 2011) ocorreu uma inversão, com a taxa média de crescimento dos BPFs $(3,7 \%)$ inferior à do restante do $\mathrm{SFN}(4,5 \%)$. A despeito do melhor desempenho dos últimos, houve queda nas taxas de crescimento de ambos os grupos, inaugurando um período de desaceleração do ritmo de aumento da oferta de crédito do conjunto do SFN, que se estendeu pelas duas próximas fases. O período marca o início da retração do produto, com deterioração das expectativas. No primeiro trimestre de 2010, a Autoridade Monetária, objetivando frear a rápida expansão do crédito, que estimulou a demanda e pressionou o aumento da taxa inflacionária, adotou uma série de medidas macroprudenciais para garantir a estabilidade do SFN (Oliveira, 2015), resultando nessa queda da aceleração das operações de crédito.

A sexta fase, (dezembro de 2011 e junho de 2013), foi marcada pelo aumento no ritmo de crescimento da oferta de crédito dos BPFs, acompanhada de desaceleração do restante do 
SFN. No âmbito da política econômica, o período foi marcado por significativas modificações. Primeiramente, a redução da taxa básica de juros, com queda da meta da taxa Selic, definida pelo Copom, de 12,50\%, em agosto de 2011, para 7,25\%, em outubro de 2012. Em segundo lugar, a agressiva política de redução dos spreads bancários, liderada pelo $\mathrm{BB}^{8}$ e secundada pela Caixa, que contribuiu de sobremaneira para o melhor desempenho dos BPFs na oferta de crédito. O Banco Central flexibilizou as políticas macroprudenciais, permitindo a expansão da oferta de crédito (Oliveira, 2015).

Essa nova aceleração na oferta de crédito dos BPFs, foi capitaneada principalmente pela recuperação no ritmo de crescimento do BNDES e do BB. A Caixa continuou exibindo taxas de crescimento muito superiores às destas duas instituições, mas em relação ao período anterior, observou aceleração bem mais moderada.

Finalmente, a sétima fase (setembro de 2013 e dezembro de 2015) ocorreu quando os BPFs voltaram a apresentar desaceleração na taxa de crescimento de suas operações, convergindo com o movimento do restante do SFN. A taxa média trimestral de crescimento da oferta de crédito dos BPFs desacelerou de 4,8\%, no período anterior, para 2,3\%, neste período, chegando ao ponto mais baixo da série em dezembro de 2015 (0,43\%). Em dezembro de 2015, a variação das operações do SFN, exclusive os BPFs, se torna negativa em 1,1\%, ponto mais baixo até do que setembro de 2009 , no auge do impacto da crise financeira internacional. O período marca o início de uma crise na economia brasileira, com queda na oferta de crédito e reflexo na taxa de crescimento. Ocorreu deterioração das expectativas dos agentes acompanhado de aumento da preferência pela liquidez das instituições financeiras em geral. A taxa Selic aumentou consideravelmente, favorecendo as aplicações das instituições financeiras em títulos e valores mobiliários, em detrimento de operações de crédito. Também marca uma campanha pública que questionou fortemente a atuação dos BPFs enquanto agentes de política pública - o argumento era que essas instituições estavam sendo usadas como instrumento político, sem a preocupação de manter as melhores práticas de gestão e garantia de sustentabilidade. Veremos nas próximas seções que esse não foi o caso.

Esta breve descrição comparativa do comportamento das operações de crédito dos BPFs e do restante do SFN é bastante útil para qualificar as principais características de seu desempenho enquanto agentes estratégicos da política econômica do governo, elemento crucial para compreender as condições de ampliação ou retração de sua oferta de crédito, no período em tela. Isto porque a referência genérica à ampliação do crédito público nem sempre considera as diferentes estratégias do governo e dos BPFs, em momentos e conjunturas diversas. $\mathrm{O}$ aumento das operações desses agentes deve ser analisado considerando-se as distintas estratégias e o papel desempenhado por cada um deles, nas variadas fases que se sucederam.

(8) O termo "agressiva" foi utilizado pelo presidente do Conselho de Administração do Banco do Brasil e SecretárioExecutivo do Ministério da Fazenda, Nelson Barbosa, em sua introdução ao Relatório de Atividades do BB de 2012. Associando a redução dos spreads à diminuição das taxas de juros dos empréstimos e ao aumento na confiança de empresários e consumidores, Barbosa apresenta a medida como parte das políticas de incentivo à produção e ao consumo domésticos, diante da desaceleração do crédito decorrente da instabilidade observada no cenário internacional (Brasil. Banco do Brasil, 2012, p.7). ( 
Para tanto, busca-se proceder a uma avaliação mais aprofundada sobre a evolução da estrutura patrimonial destas instituições, especialmente no contexto de sua atuação anticíclica.

Portanto, além da estrutura dos ativos, é também necessário compreender melhor a forma como estas instituições financiaram a expansão nas operações de crédito, detalhando a evolução de suas principais contas do passivo. A análise das operações passivas no período abordado neste trabalho, aponta para uma redução expressiva da participação dos Depósitos ${ }^{9}$, refletida em importante processo de diversificação das fontes de recursos, com diferenças estratégicas relevantes entre as principais instituições financeiras do país. Neste sentido, é crucial compreender o mecanismo e a magnitude das operações de capitalização destas instituições pelo Tesouro Nacional, bem como a relação entre estes bancos e fundos públicos, como o Fundo de Garantia por Tempo de Serviço - FGTS, no caso da Caixa, Fundo Constitucional do Centro Oeste - FCO, no caso do BB, e Fundo de Amparo ao Trabalhador FAT, no BNDES. Cabe investigar até que ponto o acesso a recursos do Tesouro Nacional e de fundos públicos viabilizou a expansão das operações de crédito, por parte destas instituições, em um contexto em que se esperava retração da atividade creditícia.

Na verdade, mais do que o acesso a recursos e fundos, também deve ser levada em consideração a estreita relação entre os bancos públicos comerciais federais e o Governo Federal, do ponto de vista da operacionalização de políticas públicas estratégicas, como o Minha Casa Minha Vida - MCMV, o Bolsa Família, o Programa Nacional de Agricultura Familiar, o Plano Safra, o Programa Nacional de Microcrédito Produtivo Orientado - PNMPO, o Programa de Sustentação do Investimento - PSI -só para citar alguns exemplos. Imagina-se que o papel desempenhado por tais bancos, como braços de política pública, possa se refletir sobre suas operações de crédito, não só pela própria natureza dos programas, mas também por facilitarem o acesso destas instituições ao mercado de crédito, ou mesmo estimularem o desenvolvimento de novos mercados.

As três próximas seções se ocupam da evolução de contas selecionadas do ativo e do passivo da Caixa, do BB e do BNDES. Para isso, foram utilizados os dados constantes nas séries "50 maiores", "IF.data" e "Balancetes", disponibilizadas pelo BCB, além de informações obtidas nos relatórios de administração destas instituições e dos fundos por elas administrados ${ }^{10}$.

\section{Caixa Econômica Federal}

A seção anterior apresentou dados comparativos entre a variação real das operações dos BPFs e o restante do SFN. Essa seção explora, em maior detalhamento, os dados da Caixa. No período entre 2003 e 2015, suas operações de crédito avançaram expressivos $1.230 \%$, em termos reais. Essa alta foi mais evidente a partir de junho de $2008(569,1 \%)$, quando suas

(9) As descrições das principais rubricas dos balanços patrimoniais utilizados neste artigo podem ser encontradas no anexo.

(10) Para mais informações, verificar Plano Contábil das Instituições do Sistema Financeiro Nacional - Cosif. 
operações registraram taxas de crescimento real superiores à média tanto do SFN $(119,1 \%)$ como dos BPFs $(243,4 \%)$.

Gráfico 2

Composição do Ativo - Caixa Econômica Federal

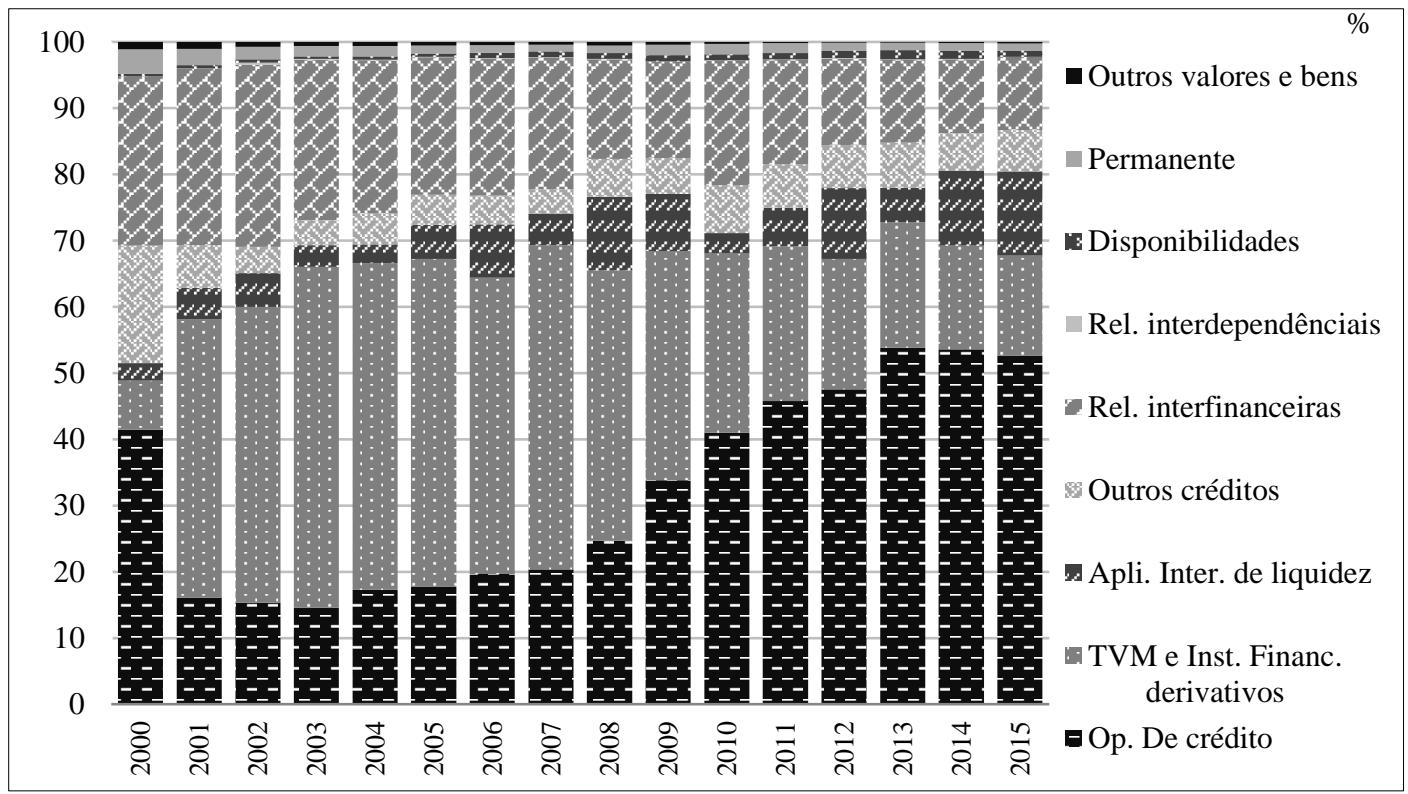

Fonte: BCB.

Do ponto de vista da composição do ativo (Gráfico 2), verificou-se significativa expansão da participação das operações de crédito no total, movimento contrário ao verificado nas operações com títulos e valores mobiliários - TVM. Considerando-se a série a partir de 2000, o ponto mínimo da participação das operações de crédito no total dos ativos ocorreu em 2003 (14,5\%), reflexo das perdas observadas entre 2000 e 2001. Essa brusca queda foi resultado das medidas do Programa de Reestruturação Patrimonial da Caixa, que tinha como objetivo enquadrá-la nas regras do Conselho Monetário Nacional e do Banco Central. Nesta ocasião, entre outras ações, os créditos habitacionais que apresentavam desequilíbrio econômico financeiro foram transferidos para a Emgea, o que ocasionou redução de $\mathrm{R} \$ 26,7$ bilhões em suas operações de crédito (Costa, 2015).

O aumento das operações de crédito da Caixa foi ininterrupto e acima da média, durante todo o período, o que se refletiu na contínua ampliação de sua participação no total dos ativos do Banco, mesmo depois do auge da atuação contracíclica. A partir de 2013, quando a taxa de crescimento das operações de crédito começa a desacelerar, sua participação no total do ativo sofre as primeiras reduções. $\mathrm{O}$ aumento de sua vocação ao crédito mostra o crescente alinhamento da instituição com os programas de governo. Assim, considerando-se a centralidade da evolução das operações no período analisado, cabe avaliação mais detalhada 
acerca das características gerais e do desempenho dos diversos tipos de operação realizados pela instituição.

O primeiro ponto a ser destacado é a presença marcante dos financiamentos imobiliários no conjunto das operações, seguidos à distância por operações de empréstimos $e$ títulos descontados (25,5\%), financiamentos de infraestrutura e desenvolvimento $(10,6 \%) \mathrm{e}$ financiamentos $(5,4 \%)$. Seu papel na oferta de crédito à habitação não é novidade, sendo um dos principais motivos para o acesso dessa instituição aos recursos do Fundo de Garantia por Tempo de Serviço (FGTS). Entretanto, a despeito da preponderância dos financiamentos imobiliários nas operações, sua participação no total da oferta de crédito observou progressiva redução, entre 2003 e 2015, de 65,0\% para 57,6\%. Apenas os financiamentos, tipo de operação menos significativo na oferta de crédito do Banco, também perdeu espaço, com queda de 9,4\% para $5,4 \%$. Na contramão desse movimento, cresceram as operações de empréstimos e títulos descontados (de $22,5 \%$ para $24,4 \%$ ), refletindo a estratégia do governo federal em aumentar a inserção financeira e o acesso ao crédito da população; e de financiamentos de infraestrutura e desenvolvimento (de 3,1\% para 10,6\%), calçado no acesso aos recursos do FGTS. Os financiamentos rurais e agroindustriais, que contam com pequena participação $(1,1 \%)$ no total das operações, não eram realizados em 2003, tendo sido iniciados apenas em 2012 e fazem parte do projeto de diversificação de produtos adotados pelos BPFs.

Gráfico 3

Operações de crédito - Caixa

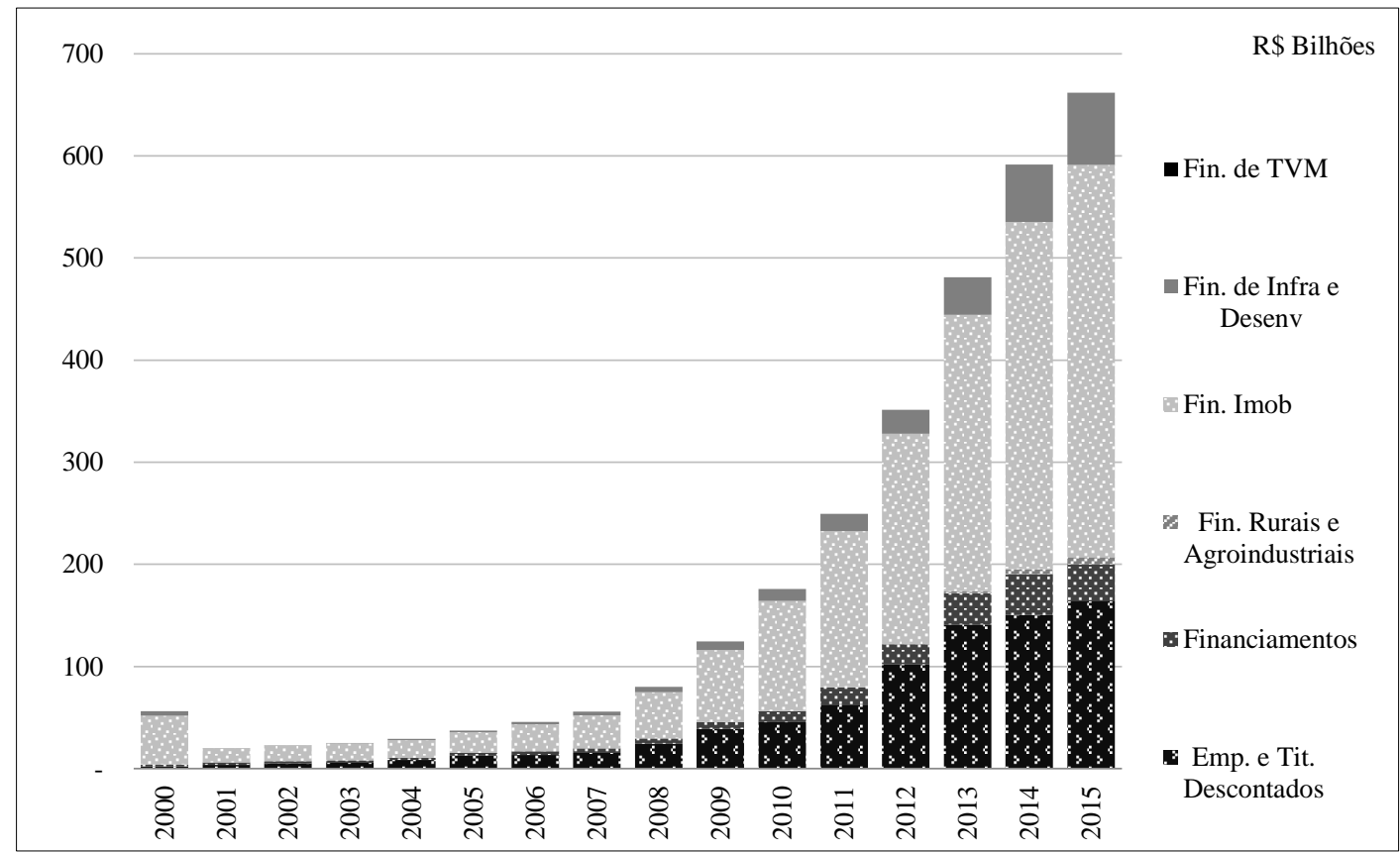

Fonte: BCB. 
As taxas de crescimento reais interanuais de cada tipo de operação realizada são reveladoras das estratégias adotadas pela Caixa, em conjunturas distintas, que resultaram no movimento geral descrito. As operações de financiamento imobiliário e de infraestrutura e desenvolvimento foram os principais alvos do programa de reestruturação, entre 2000 e 2001, registrando quedas de 74,1\% e 92,8\%, respectivamente. Entre 2002 e 2005, enquanto os financiamentos de infraestrutura e desenvolvimento se recuperaram, os financiamentos imobiliários se mantiveram praticamente estáveis. Nesse mesmo período, as operações de empréstimos e títulos descontados, que representam o que usualmente se denomina "crédito livre", foram as principais motoras do crescimento do saldo total, exibindo taxas superiores às do conjunto das operações. Esse aumento seguiu a tendência da política de governo que objetivava aumentar o crédito a população de forma a aquecer a economia e criar, com isso, um ciclo virtuoso de investimento e crescimento (Bielschowsky, 2012, v. 21). Os anos de 2006 e 2007 assistiram a breve reversão desta tendência, com recuperação do financiamento imobiliário e relativa desaceleração dos empréstimos.

No contexto do auge dos efeitos da crise financeira internacional, entre 2008 e 2009, a atuação contracíclica da Caixa se refletiu em aceleração na oferta de todos os tipos de operação de crédito. No entanto, a despeito das substantivas taxas apresentadas pelos financiamentos imobiliários e de infraestrutura, foram os empréstimos e títulos descontados que exibiram as variações mais elevadas.

Ainda assim, o movimento propiciou novo estímulo aos financiamentos imobiliários, que passaram a crescer em ritmo mais próximo dos demais tipos de operação, mantendo taxas de dois dígitos de crescimento até 2015, mesmo que sempre inferiores à variação observada em 2009. Os empréstimos, por outro lado, exibiram ritmo de crescimento mais errático, com acelerações e desacelerações abruptas, a depender da conjuntura, ainda que tenham apresentado taxas sempre expressivas, até 2014. Na dinâmica que se estabeleceu entre esses dois tipos de operações, após o período mais sensível da crise financeira, o crédito habitacional apresentou melhor desempenho entre 2010 e 2011, sendo ultrapassado novamente pelos empréstimos em 2012 e 2013, diante da conjuntura de forte expansão dos últimos, em decorrência da redução dos spreads. A partir de 2014, o fraco desempenho da economia afetou imediatamente os empréstimos, que sofrem abrupta desaceleração, enquanto o financiamento habitacional manteve-se crescendo. Ao mesmo tempo, os financiamentos de infraestrutura $e$ desenvolvimento exibiram trajetória mais constante: aceleração do crescimento, entre 2005 e 2009, reflexo dos investimentos no PAC; seguido de diminuição no ritmo de expansão, daí em diante - acima da taxa de crescimento do total das operações e dos financiamentos imobiliários em praticamente todos os anos.

Em suma, se é verdade que o crédito habitacional ainda representa a principal modalidade da atividade creditícia da Caixa, como esperava-se, é possível afirmar que o Banco atuou fortemente na diversificação de sua carteira, com ênfase em campos como infraestrutura, e aproveitando as conjunturas favoráveis para ampliar suas operações em empréstimos. 
Por sua vez, a análise das contas passivas da Caixa, evidencia mudanças substantivas no padrão de financiamento de suas atividades, ajudando a esclarecer as condições para a expansão de suas operações de crédito. Entre os anos de 2003 e 2015, a Caixa adotou a estratégia de diversificar suas fontes de recursos (ver Gráfico 4). Assim, ocorreu redução na participação dos depósitos no conjunto de suas operações passivas, além de outras três contas que também seguiram esse movimento: 1. obrigações por operações compromissadas, cuja perda de participação contrasta com o crescimento bastante relevante em todos os demais; 2 . obrigações por empréstimos e repasses, principal fonte de recursos à disposição da Caixa; e 3. outras obrigações cuja magnitude do crescimento em participação se destaca no exemplo da Caixa.

Apesar do crescimento real de 180,1\% no volume dos depósitos totais, entre 2003 e 2015, a participação desta rubrica no total do passivo caiu de $56,0 \%$ para $38,7 \%$. Este movimento decorreu, fundamentalmente, da menor taxa de crescimento dos depósitos em poupança, que correspondia a mais de $30 \%$ do passivo total até 2011 , quando entrou em trajetória de intensa desaceleração, relativamente às demais rubricas, encerrando 2015 com participação de apenas $20,5 \%$.

Gráfico 4

Composição do passivo circulante e exigível - Caixa

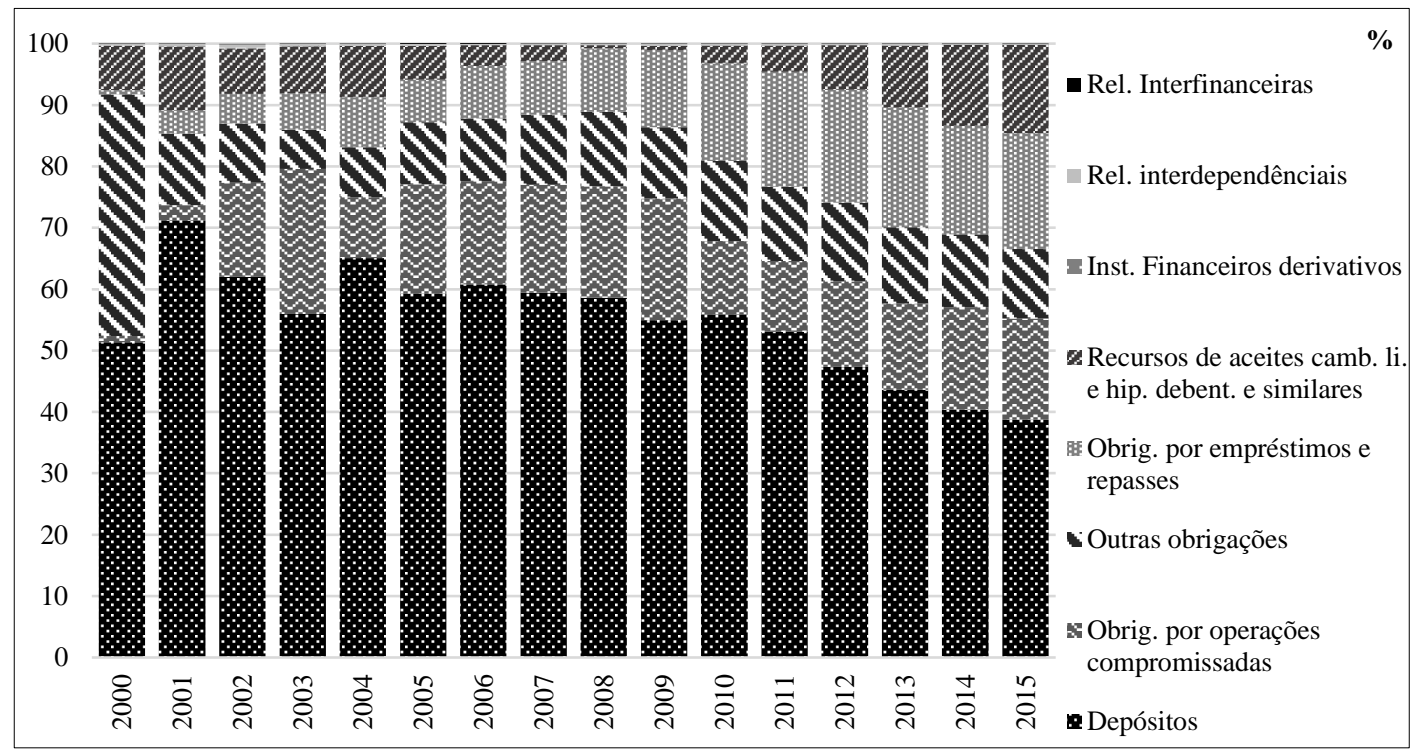

Fonte: BCB.

A queda na participação dos depósitos em poupança é bastante sintomática, pois, juntamente com o FGTS, a conta corresponde a uma das principais fontes de recursos para 
operações de financiamento imobiliário. Se é verdade que a expansão nas suas operações de crédito não foi puxada exclusivamente pelos financiamentos imobiliários, também é preciso reconhecer que esta modalidade de crédito tem participação bastante relevante em suas operações ${ }^{11}$, sendo fundamental identificar as fontes de recursos que sustentaram seu crescimento. Como o ritmo de expansão dos depósitos em poupança $(173,0 \%)$ foi menos acentuado do que o aumento observado nos financiamentos imobiliários (1.060,9\%), no período entre 2003 e 2015, pode-se conjeturar que a expansão dos últimos teve que ser sustentada.

Gráfico 5

Participação dos empréstimos e repasses no passivo circulante exigível, por modalidade - Caixa

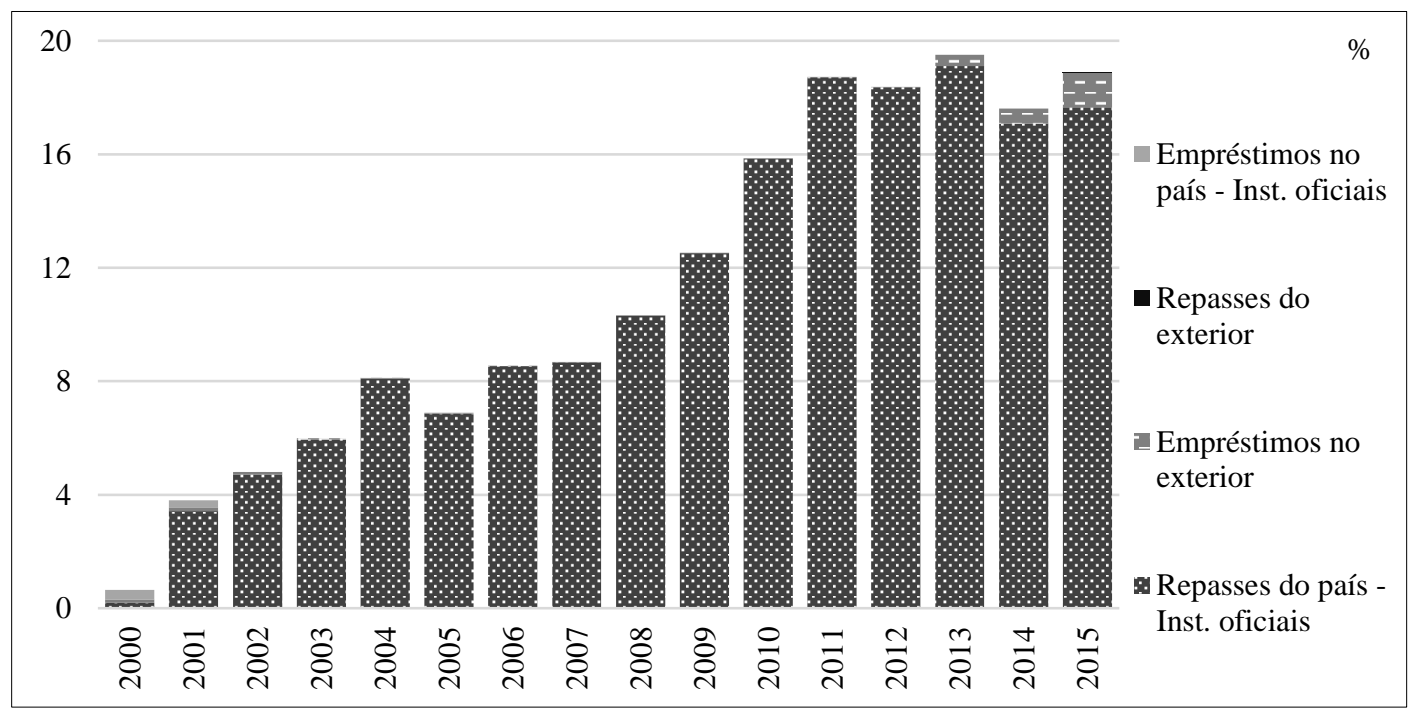

Fonte: BCB.

De fato, dentre as contas do passivo circulante e exigível (PCE) da Caixa, a que mais ganhou em participação, entre 2003 e 2015, foi obrigações por empréstimos e repasses, como reflexo, fundamentalmente, da significativa expansão do subitem Repasses do País Instituições Oficiais, que registrou crescimento de 11,7 p.p., atingindo 17,7\% (Gráfico 5), enquanto os demais subitens tiveram contribuição mais modesta. A expansão dos repasses de instituições oficiais, ainda que tenha registrado taxas interanuais reais de crescimento substantivas em quase todos os anos analisados, verificou maior aceleração no período entre 2005 e 2011, quando se observa elevação de 6,9\% para 18,7\% em sua participação.

(11) Além da grande participação dos financiamentos imobiliários nas operações da Caixa, cabe destacar a forte presença deste banco no conjunto do crédito imobiliário do SFN, que chegava a 69,4\% em 2015. 
Gráfico 6

Participação dos repasses de instituições oficiais no passivo circulante exigível - Caixa

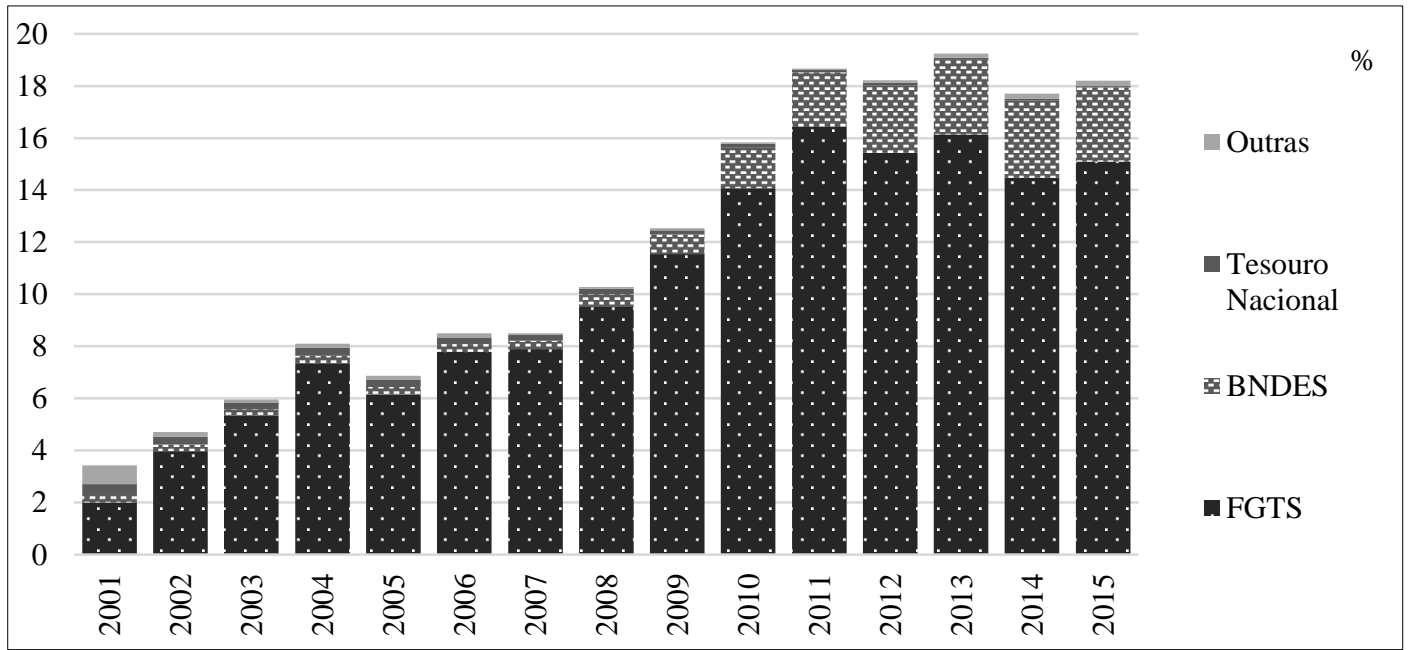

Fonte: Relatórios de Administração - Caixa Econômica Federal (2002 a 2015).

No subitem Repasses do País - Instituições Oficiais há, no período, registros de repasses originados em quatro classes diferentes de instituições oficiais (Gráfico 6): FGTS, BNDES, Tesouro Nacional e Outras. Os recursos oriundos do FGTS são os mais representativos dentre todas, oscilando em torno de $90 \%$ do total, até 2010, quando os recursos do BNDES começaram a ganhar espaço. De todo modo, o crescente peso do FGTS dentre de repasses de se fez sentir, inclusive, em sua participação no total do passivo, que saltou de 5,3\%, em 2003, para 15,1\%, em 2015, impulsionada por crescimento real no montante destes recursos superior a $1.000 \%$, neste mesmo período.

Dois fatores simultâneos parecem ter concorrido para possibilitar o crescimento da conta de repasses do FGTS e o consequente aumento de sua participação no conjunto das contas passivas da Caixa. Primeiro, o aumento verificado no montante de recursos disponíveis no próprio Fundo. Entre 2003 e 2015, o total do ativo do FGTS registrou crescimento real de $47,7 \%$, ao passo que os recursos direcionados para aplicações em financiamentos imobiliários e de saneamento, infraestrutura e desenvolvimento, considerando todos os agentes financeiros, registrou aumento real de 77,5\%, taxa média anual de 4,9\%. Ao final de 2015, o FGTS contava com ativo de $\mathrm{R} \$ 457,6$ bilhões, dos quais $53,3 \%$ estavam aplicados naquelas duas modalidades de financiamento ( $\mathrm{R} \$ 243,9$ bilhões).

Além do crescimento do próprio FGTS, houve aumento na parcela de seus recursos que passaram a ser aplicados diretamente pela Caixa. A relação entre a Caixa e o FGTS é bastante conhecida em função de seu papel de agente operador do fundo, o que não significa que todas as aplicações de seus recursos sejam realizadas diretamente pela Caixa. No que diz respeito aos financiamentos habitacional e de saneamento básico, infraestrutura e 
desenvolvimento - áreas prioritárias para aplicação dos recursos - a Lei n. 8.036 de maio de 1990, que dispõe sobre o FGTS, estabelece a possibilidade de aplicação dos recursos por meio do próprio agente operador ("Agente Financeiro Caixa") ou por meio de outras instituições autorizadas (Outros Agentes Financeiros). No período analisado, a participação dos financiamentos realizados diretamente pela Caixa registrou aumento de 17,6\% para 83,2\% (Gráfico 7), expansão que ocorreu tanto nas operações de crédito habitacional, quanto nas de infraestrutura, saneamento e desenvolvimento. Isto é, além do crescimento acentuado nos recursos do FGTS, houve, também, aumento progressivo na parcela desses recursos aplicada diretamente pela Caixa, o que se refletiu na sua conta de repasses do passivo. A magnitude do crescimento observado por esta rubrica e a participação que adquiriu em relação ao PCE da Caixa é sugestiva da importância que ela teve como fonte de recursos para a expansão verificada nos financiamentos imobiliários e de infraestrutura e desenvolvimento.

Gráfico 7

Participação do Agente Financeiro Caixa no total dos financiamentos concedidos com recursos do FGTS

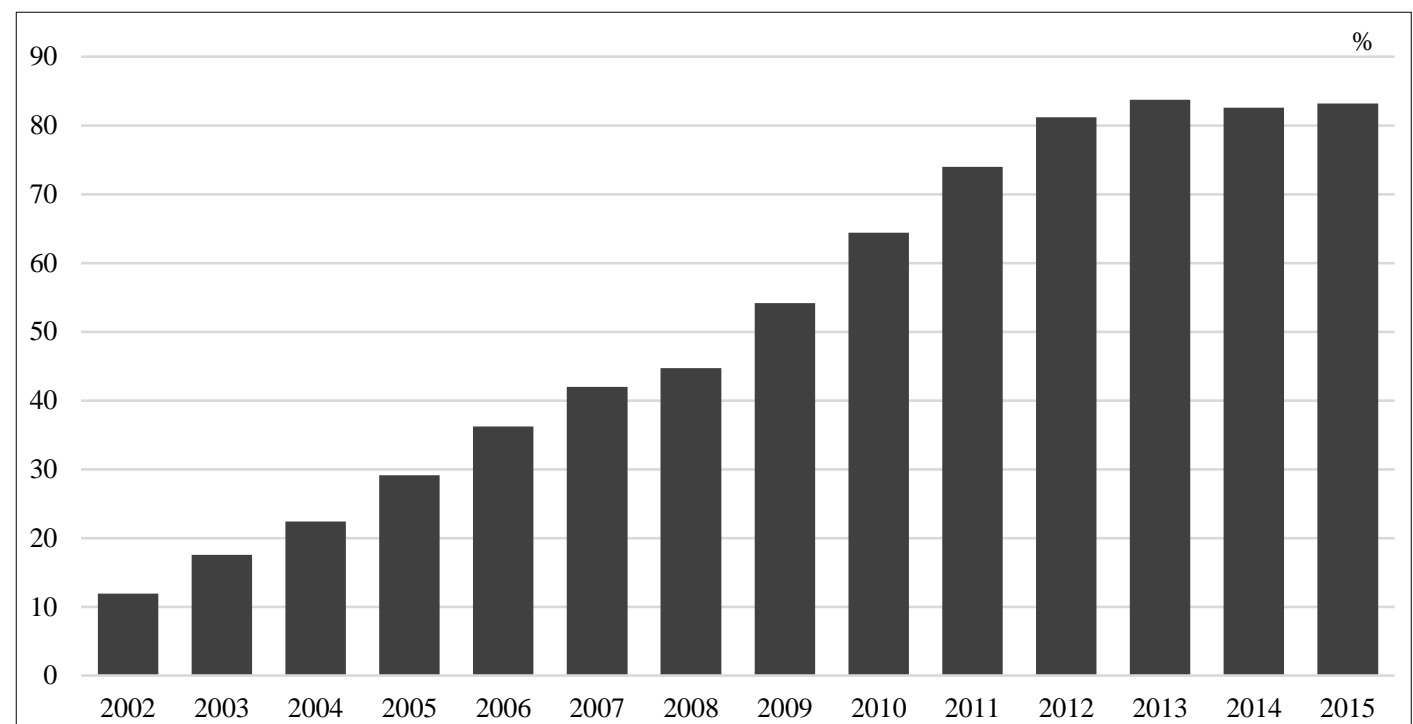

Fonte: Balanços Patrimoniais do FGTS (2003 a 2015).

Ainda, como já indicado, a Caixa apostou em outros instrumentos para sustentar a ampliação de suas operações. A terceira conta com movimentação relevante, entre 2003 e 2015, foi outras obrigações, que cresceu $616,4 \%$ e cuja participação no total do PCE subiu de $6,4 \%$ para $11,3 \%$. Esta conta contempla diversos tipos de obrigações, com diferentes composições em cada um dos anos, de modo que sua análise depende de esforço anterior de classificação, para o qual foram utilizados os relatórios de Administração. Para efeitos analíticos, agregamos no subitem Obrigações por loterias, fundos e programas sociais, as rubricas relativas a: i) operações com loterias; ii) fundos e programas sociais; e iii) fundos financeiros e de 
desenvolvimento, que são apresentadas individualmente nos relatórios de administração da Caixa.

Os recursos relativos às operações com lotéricas são pouco representativos. As obrigações por fundos financeiros e de desenvolvimento apresentam valores mais modestos em relação a programas sociais, exceto para o período entre 2004 e 2008 , quando ambos rivalizam em importância. O agregado destas três rubricas totalizava $\mathrm{R} \$ 12,2$ bilhões em 2015 , crescendo 218,9\% em termos reais, em relação a 2003. Ainda assim, sua importância é relativamente modesta.

\section{Gráfico 8}

Participação de outras obrigações, no total do passivo circulante exigível, por subitem - Caixa

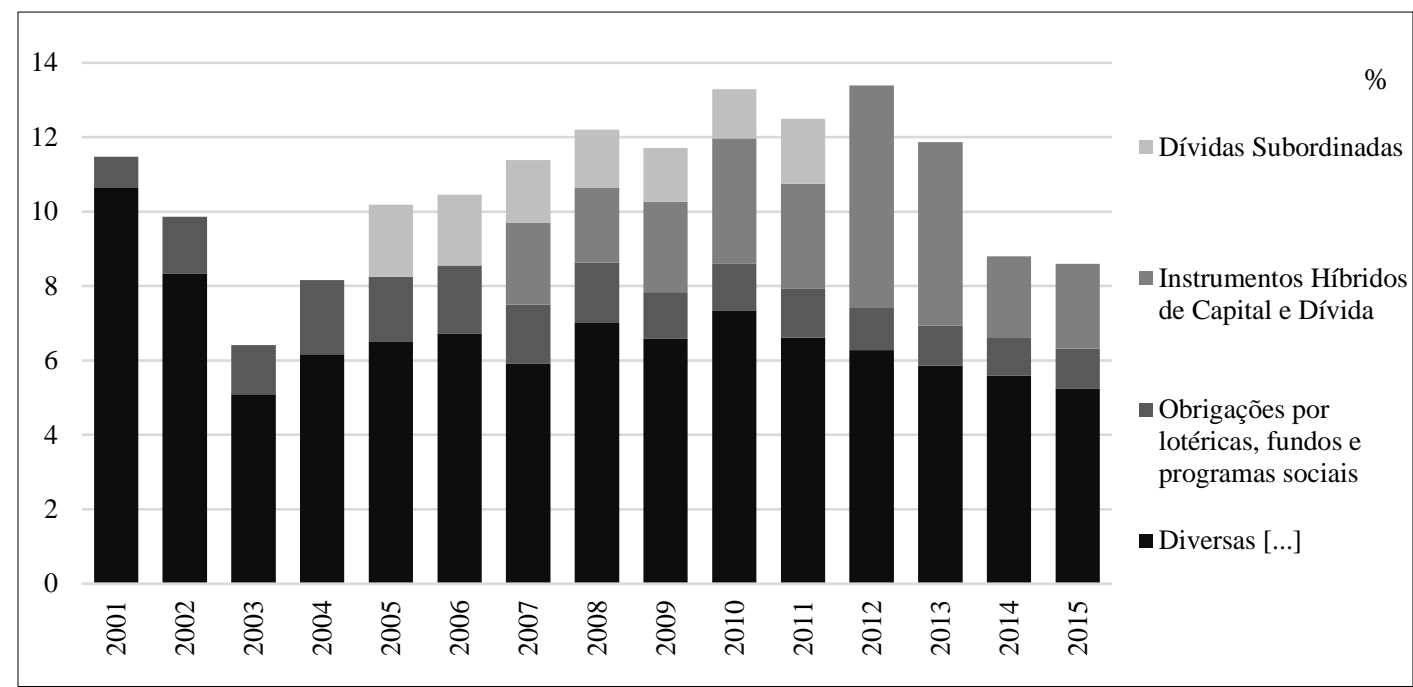

Fonte: Relatórios de Administração - Caixa Econômica Federal (2002 a 2015).

O subitem dividas subordinadas, tem registro apenas entre os anos de 2005 e 2011, correspondendo a participação entre 1,3\% e 1,9\% do PCE. Segundo notas dos relatórios de administração, este subitem se refere à conversão de dívidas do Banco junto ao FGTS em dívidas subordinadas, que podem compor o nível II do Patrimônio de Referência (PR), para efeitos de cálculo dos limites do Acordo de Basiléia ${ }^{12}$. Esta operação, de R \$ 3,4 bilhões, foi autorizada pelo BCB em 2005, e teria o início de retorno da dívida contratada em março de 2013, data que foi antecipada pela Caixa para o exercício de 2011. Finalmente, os Instrumentos Híbridos de Capital e Dívida, que têm início em 2007 e ganham espaço progressivamente, chegando a 6,0\% do total do passivo em 2012, quando começam a ter sua participação reduzida. Este instrumento, criado por meio da Lei n. 11.485 de 2007, possibilitou que a União

(12) Conforme disposto pela Resolução do CMN n. 2.837, de 2001. Segundo esta mesma norma, os instrumentos híbridos de capital e dívida também poderiam compor o nível II do Patrimônio de Referência das instituições financeiras, utilizado para o cálculo do índice de Basileia. 
capitalizasse o Banco por meio de "empréstimos perpétuos", estabelecidos em contrato particular, sem prazo de amortização e com pagamento mensal de juros e atualização monetária pelo IPCA. O valor aportado à Caixa como instrumentos híbridos de capital e dívida, entre 2007 e 2010, foi de R\$ 13 bilhões e, assim como no caso das dívidas subordinadas, foi considerado como elegível a nível de capital II, possibilitando ao Banco maior alavancagem, nos marcos do Acordo de Basiléia ${ }^{13}$.

Em resumo, podemos inferir da análise que, a despeito da queda em participação, a expansão das operações de crédito foi concentrada em empréstimos e financiamentos imobiliários, que continua sendo a principal rubrica do Banco. Em contrapartida, apesar de ter participação menor no conjunto das operações, financiamentos de infraestrutura $e$ desenvolvimento foram a modalidade mais dinâmica em praticamente todo o período analisado e têm presença cada vez mais importante nas operações de crédito, refletindo a crescente importância da instituição nos esforços públicos em diminuir o gap de infraestrutura no Brasil. A atuação anticíclica dessa instituição foi essencial para a estratégia do governo federal e no auge da crise financeira internacional, o aumento nas operações de crédito foi generalizado, mas as taxas mais elevadas foram registradas na modalidade dos Empréstimos e a partir de 2012, as maiores taxas foram verificadas ou nos financiamentos imobiliários ou nos de infraestrutura e desenvolvimento. No mesmo sentido, pôde-se concluir que tanto o financiamento imobiliário, que é o mais relevante, quanto o de infraestrutura e desenvolvimento, que teve o desempenho geral mais dinâmico, são beneficiados pelo acesso a recursos do FGTS, que aumentaram substancialmente. Assim como a diversificação ocorrida nas ofertas de crédito, o banco atuou no sentido de aumentar suas fontes de receitas, inovando em emissão de títulos e maior utilização dos recursos disponíveis, garantindo mais segurança ao seu balanço.

\section{Banco do Brasil ${ }^{14}$}

Assim como a Caixa, o Banco do Brasil apresentou crescimento das operações de crédito superior ao do SFN, ainda que o perfil de suas contas ativas guarde diferenças importantes, quando comparado às da Caixa. No período entre 2003 e 2015 suas operações avançaram 405\%, em termos reais. Entre junho de 2008 e dezembro de 2015, o total das

(13) Para mais informações sobre a criação deste instrumento e seus impactos na relação entre o Tesouro Nacional e a Caixa Econômica Federal, ver Costa (2015, p. 11, 12).

(14) Importante destacar que os dados apresentados nesta seção foram obtidos na série Balancetes, do Banco Central do Brasil, e dizem respeito à instituição financeira independente "Banco do Brasil". No caso deste Banco, eles diferem dos dados apresentados nas séries 50 maiores e IF.data, que trazem informações do conglomerado financeiro. No período em que esta pesquisa foi realizada, a série Balancetes não disponibilizava dados dos conglomerados financeiros, apenas das instituições financeiras independentes. Apesar da divergência, a opção pela utilização da série Balancetes se justifica pela maior desagregação dos dados apresentados, indo até o nível 3 do Cosif, o que possibilita análise mais detalhada. Importante destacar que, para a Caixa e o BNDES, os dados referentes à instituição financeira independente nos Balancetes são equivalentes aos do conglomerado financeiro, nas outras duas séries. Para esclarecimentos acerca da diferença entre "Instituição Financeira Independente" e "Conglomerado Financeiro", ver Oliveira (2015, p. 12 e seguintes). 
operações registrou crescimento de $152 \%$, em termos reais - ambas variações substantivas. Considerando-se o perfil de suas operações ativas, entre 2000 e 2015 as principais alterações ocorreram na distribuição das aplicações em três contas, a saber, operações de crédito, aplicações interfinanceiras de liquidez e títulos e valores mobiliários. Enquanto as duas primeiras registraram aumento, a terceira apresentou perda de participação no ativo total do banco (Gráfico 9).

Gráfico 9

Composição do Ativo BB

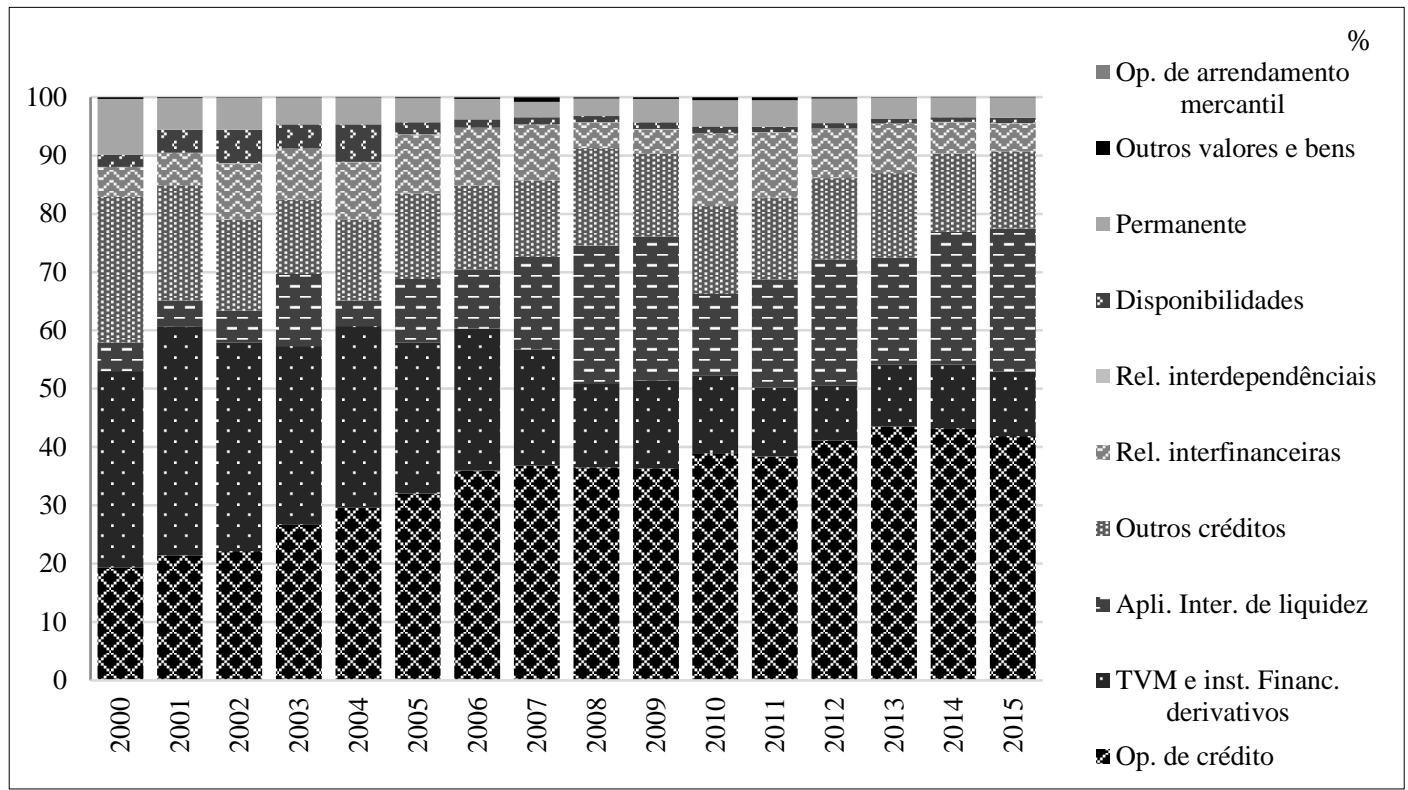

Fonte: BCB.

O crescimento na participação das operações de crédito sobre o total do ativo do BB acompanhou o movimento geral descrito para a Caixa, com a ressalva de que a evolução desta conta, no BB, registrou, ao longo de todo o período considerado, taxas de crescimento menores e com maior oscilação. Partindo de 2003, quando esta conta chegou ao ponto mínimo da série (26,7\% do ativo total), a rubrica operações de crédito ganhou espaço progressivamente até 2007, período em que atingiu 36,8\%. No auge da atuação contracíclica realizada pela instituição, entre 2008 e 2009 a participação do crédito manteve-se surpreendentemente estável, no mesmo patamar atingido ao final de 2007. Em 2010, aumenta novamente, para $39,0 \%$ do total das contas ativas, atingindo 43,5\% em 2013, maior nível da série histórica. Ao final de 2015, depois de uma década de progressiva expansão, a despeito dos dois últimos anos de perdas consecutivas de participação, atingiu 41,5\% do ativo total (ver Gráfico 9). 
Gráfico 10

Operações de crédito - BB

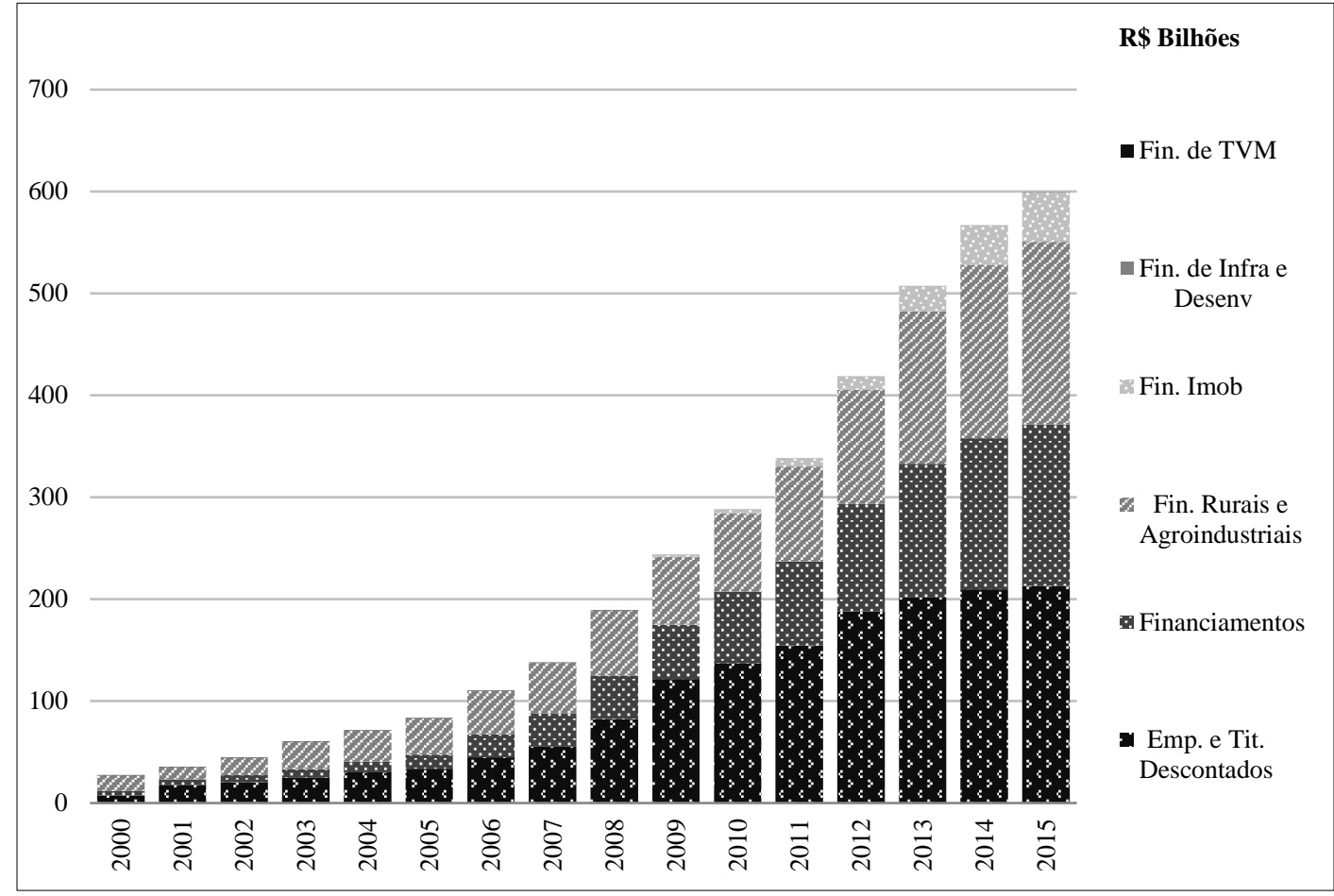

Fonte: BCB.

Isoladamente, o aumento das operações de crédito não necessariamente representa melhora na qualidade da evolução do crédito ofertado. A dinâmica da rubrica e as estratégias adotadas, nas distintas conjunturas analisadas, podem ser melhor compreendidas pela comparação entre a evolução relativa de cada um dos tipos de operação ${ }^{15}$ (Gráfico 10). Entre 2003 e 2015, a preponderância original dos empréstimos e títulos descontados e dos financiamentos rurais e agroindustriais foi progressivamente diluída pelo crescimento de duas novas modalidades: i) os financiamentos, cuja principal componente diz respeito às operações de repasse de recursos do BNDES; e ii) os financiamentos imobiliários, ramo em que a instituição ingressou em 2008 e que rapidamente se tornou relevante vetor de crescimento da oferta de crédito.

Os financiamentos rurais e agroindustriais detinham participação, em 2003, de 44,8\% do total das operações de crédito, o que fazia desta modalidade a mais representativa. Principal responsável pela execução dos planos governamentais de estímulo ao setor agrário, o papel

(15) De acordo com o Cosif, (Brasil. Banco Central do Brasil. ), a rubrica operações de crédito (1.6.0.00.00-1) engloba empréstimos e direitos creditórios descontados (1.6.1.00.00-4), financiamentos (1.6.2.00.00-7), financiamentos rurais $e$ agroindustriais (1.6.3.00.00-0), financiamentos imobiliários (1.6.4.00.00-3), financiamento de títulos e valores mobiliários (1.6.5.00.00-6), financiamento de infraestrutura e desenvolvimento (1.6.6.00.00-9), operações de crédito vinculados a cessão (1.6.8.00.00-5) e provisões para operações de crédito (1.6.9.00.00-8). 
deste tipo de crédito no conjunto da instituição não é surpreendente. Entre 2003 e 2015 os financiamentos desta natureza registraram crescimento de 230,5\%, em termos reais. Apesar de elevada, esta taxa foi inferior à do conjunto das operações de crédito do Banco (405\%). Como resultado, os financiamentos rurais perderam participação no total dessas operações, atingindo $29,8 \%$ em 2015.

Outra modalidade representativa são os empréstimos e títulos descontados, que perfaziam 42,0\% do total em 2003 e apresentaram crescimento real de 320,1\% entre 2003 e 2015, mas abaixo da taxa de variação do conjunto das operações. Com isso, ao final da série, sua participação no total caiu para 35,6\%. Vale destacar que, como no caso da Caixa, foi esta a principal modalidade de crédito ativada pelo BB para sustentar sua oferta de crédito, no contexto da crise.

Ainda quanto aos empréstimos, a atuação do BB foi central para viabilizar a política de redução dos spreads bancários, em 2012. Naquele contexto, o relatório de administração apresentado pela instituição ressalta os desafios da indústria financeira em "adaptar-se à conjuntura de forte queda das taxas de juros e de redução dos spreads, buscando eficiência operacional e revisando o portfólio de produtos e serviços bancários" (Brasil. Banco do Brasil., 2013, p. 47). De fato, o ano registrou importante aceleração no crescimento da oferta desta modalidade de crédito, que teve variação real de $15,5 \%$ em relação ao ano anterior. Destacase, no entanto, que este crescimento foi menor do que a variação de outras duas modalidadesfinanciamentos e financiamentos imobiliários.

A entrada do BB nos financiamentos imobiliários ocorreu, ainda timidamente, em 2008, a partir de quando registrou taxas de crescimento excepcionalmente elevadas e superiores às das demais modalidades, evidenciando a estratégia ativa da instituição para ocupar espaço neste mercado. Assim, em apenas sete anos, essa rubrica passou a ocupar 8,1\% do total de suas operações de crédito. Em 2015, quando o total de sua oferta creditícia registrou retração real de 5,2\%, financiamentos imobiliários continuou sua avançando, à taxa real de $14,8 \%$.

A mais importante contribuição para a dinâmica da expansão das operações foi o desempenho observado pela modalidade dos financiamentos, que apresentou crescimento real de $898,2 \%$ entre 2003 e 2015 , saindo de $13,1 \%$ do total das operações de crédito em 2003, para $26,4 \%$ ao final de 2015. A despeito de registrar elevadas taxas de crescimento real anual em toda a série, o momento de maior expansão dessas operações ocorreu entre 2005 e 2007, quando passou de $13,1 \%$ para $23,9 \%$ do total das operações de crédito. Trata-se de expansão anterior ao período da crise financeira internacional, quando houve, inclusive, desaceleração no crescimento desta modalidade. Após 2007, a rubrica foi impulsionada pelos empréstimos às obras do PAC.

Ainda assim, é conhecido o papel destacado do BB enquanto agente repassador de recursos do BNDES, fator que ajuda a explicar a expansão dos financiamentos. A estrutura de operações de repasse do BNDES a outras agentes financeiros dos setores privado e público será melhor desenvolvida, na próxima seção. No entanto, pode-se adiantar que o BNDES trabalha como uma instituição de segundo piso, ou seja, parte de seus financiamentos ocorre 
por meio de outras instituições cadastradas. Deste modo, o BNDES consegue atuar de forma mais capilar no território nacional e mais efetiva nos diversos setores da economia. Segundo dados referentes ao exercício de 2014, o BB respondia por 22,9\% do total dos desembolsos das operações indiretas do BNDES, a maior participação dentre todos os demais agentes repassadores, públicos ou privados.

Sobre as duas modalidades que mais ganharam espaço no conjunto das operações do $\mathrm{BB}$, cabe ainda uma observação. No que diz respeito ao crescimento dos financiamentos, destaca-se que o período de maior dinamismo deste tipo de crédito foi entre 2005 e 2007, ou seja, antes da deflagração da crise global, ainda que tenha crescido a taxas usualmente superiores às do conjunto das operações de crédito durante todo o período analisado. Já os financiamentos imobiliários foram implantados apenas durante o auge da referida crise, a partir de quando se tornaram elemento fundamental para a dinâmica de expansão da atividade creditícia desta instituição.

Gráfico 11

Composição do passivo circulante e exigível - BB

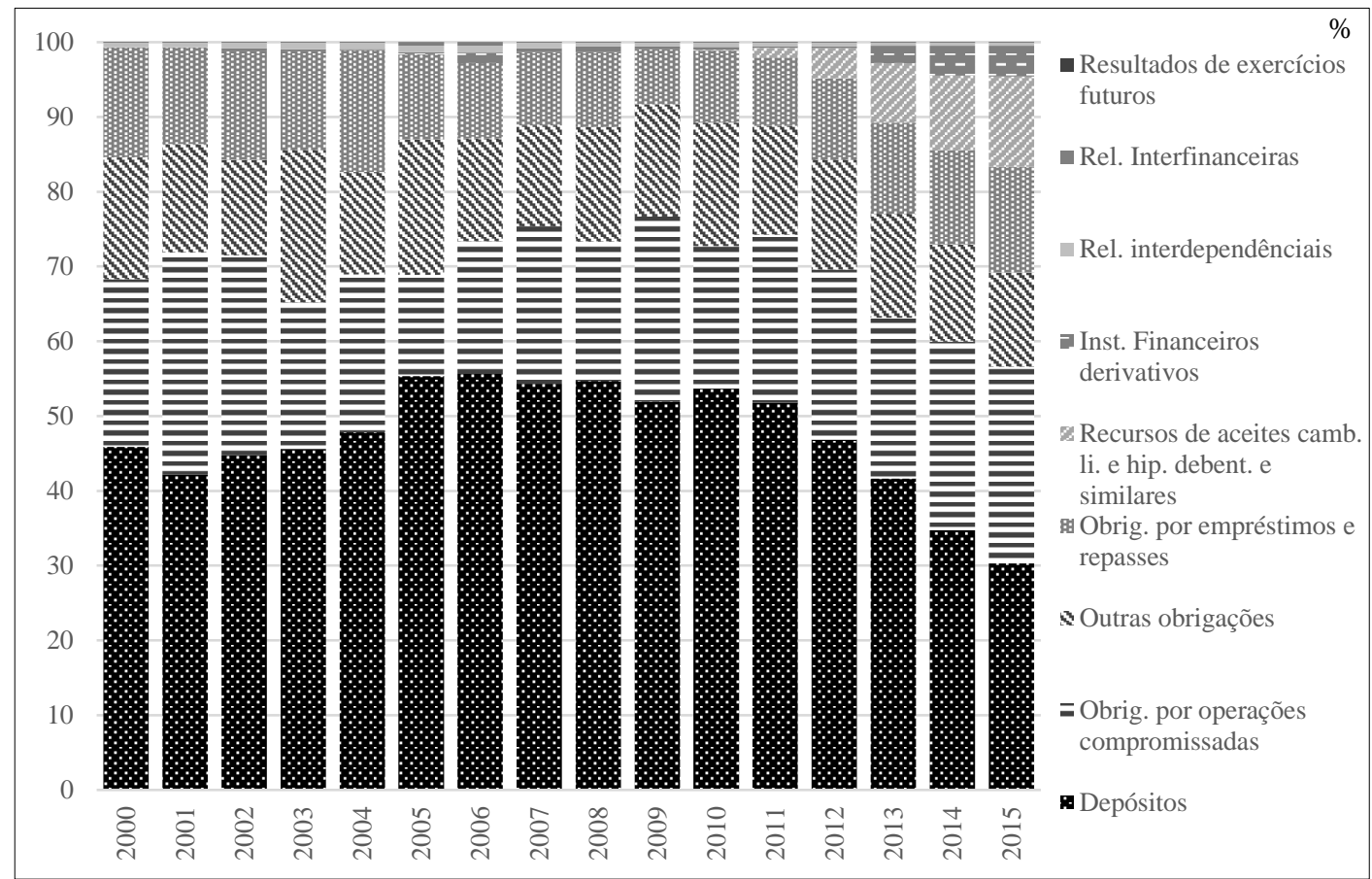

Fonte: BCB.

Por sua vez, a análise do Passível Exigível Circulante do BB (ver Gráfico 11) evidencia movimento semelhante ao da Caixa, no que diz respeito à diversificação das fontes de recursos, ainda que em contas diferentes. O BB registrou perda expressiva de participação da conta depósitos totais no total do PCE, com redução de 15,3 p.p. entre 2003 e 2015 (o equivalente a $\mathrm{R} \$ 206,4$ trilhões em valores de 2015). 
Além desta, a conta outras obrigações também verificou significativa perda de espaço, de 7,9 p.p., no mesmo período. Como contrapartida, as três contas que tiveram aumento de participação em relação ao total do PCE foram Recursos de Aceites Cambiais, Letras Imobiliárias e Hipotecárias, Debêntures e Similares, obrigações por operações compromissadas e instrumentos financeiros derivativos.

Gráfico 12

Participação dos depósitos no passivo circulante exigível, por modalidade - BB

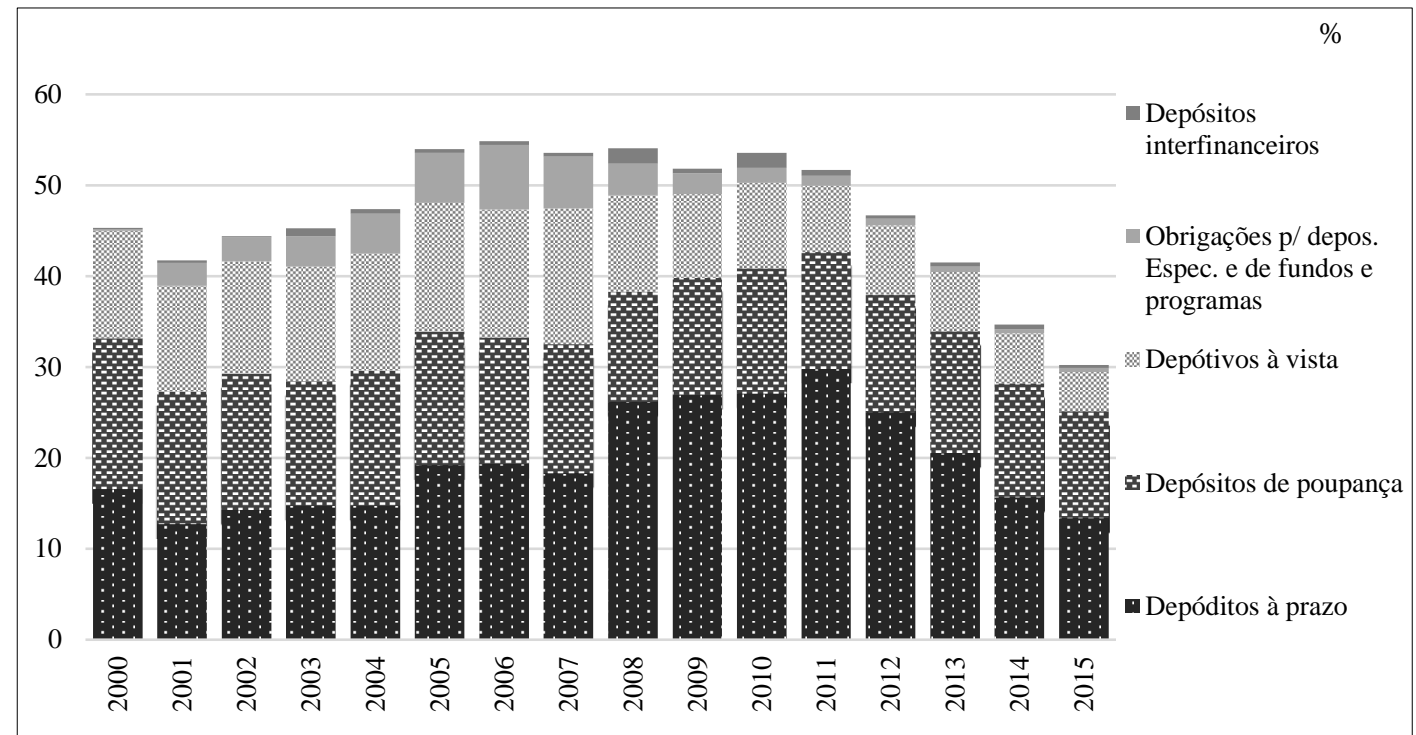

Fonte: BCB.

Assim como no caso da Caixa, a perda de espaço dos depósitos totais (Gráfico 12) não ocorreu em função da queda nos recursos depositados, que cresceram 112,6\% em termos reais, entre 2003 e 2015, mas, sim, da relativa desaceleração do ritmo de crescimento dessas captações vis-à-vis às demais. Considerando-se os tipos de depósitos, contudo, o movimento observado no BB evidencia diferenças em relação à Caixa, com queda mais acentuada na participação dos depósitos à vista, que representavam 12,6\% do total em 2003 e caíram a 4,3\%, em 2015. No que tange os depósitos em poupança, a queda menos intensa do que a observada na Caixa reflete também o menor espaço ocupado por esta conta na estrutura patrimonial do BB, que em 2003 representava 13,7\% e passou para 11,8\% do passivo total em 2015.

Em todo caso, a despeito do movimento destas duas rubricas, que foram perdendo espaço progressivamente, a modalidade de depósito mais relevante no BB continuou sendo os Depósitos a Prazo, com participação de 13,3\% no total do passivo em 2015, ligeiramente inferior aos $14,7 \%$ verificado em 2003. Os depósitos a prazo compreendem, basicamente, quatro tipos distintos de depósitos: a) depósitos em Moeda Nacional; b) depósitos Judiciais; c) depósitos do Fundo de Amparo aos Trabalhadores - FAT; e d) depósitos do Fundo de Aval para Geração de Emprego e Renda - Funproger. Ao longo do período analisado, a 
participação dos depósitos a prazo em Moeda Nacional foi a mais significativa do grupo, oscilando entre os patamares de 9,3\% e 20,3\% do total. A partir de 2014, os depósitos Judiciais, segunda maior rubrica em todos os anos anteriores, passam à frente dos depósitos em Moeda Nacional e chegaram a representar 8,6\% do conjunto das operações, em 2015. Os depósitos do FAT e do Funproger ${ }^{16}$, por outro lado, apresentaram valores bem menos significativos, com participação progressivamente menor, atingindo o ponto mínimo de $0,3 \%$ no total, em 2015. A perda de participação de recursos oriundos do FAT e do Funproger no período chama atenção, pois chegaram a representar 6,8\% das operações passivas do Banco, em 2006.

Dos itens que compõem a conta, a contribuição mais relevante para a expansão entre 2005 e 2013, foi dos depósitos a prazo em Moeda Nacional, ao passo que os demais permaneceram relativamente estáveis, ou mesmo caíram. Assim como na Caixa, portanto, os depósitos totais continuam representando parte significativa das operações passivas do BB, apesar de sua substantiva perda de participação relativa.

Gráfico 13

Participação dos depósitos a prazo no passivo circulante exigível, por tipo - BB

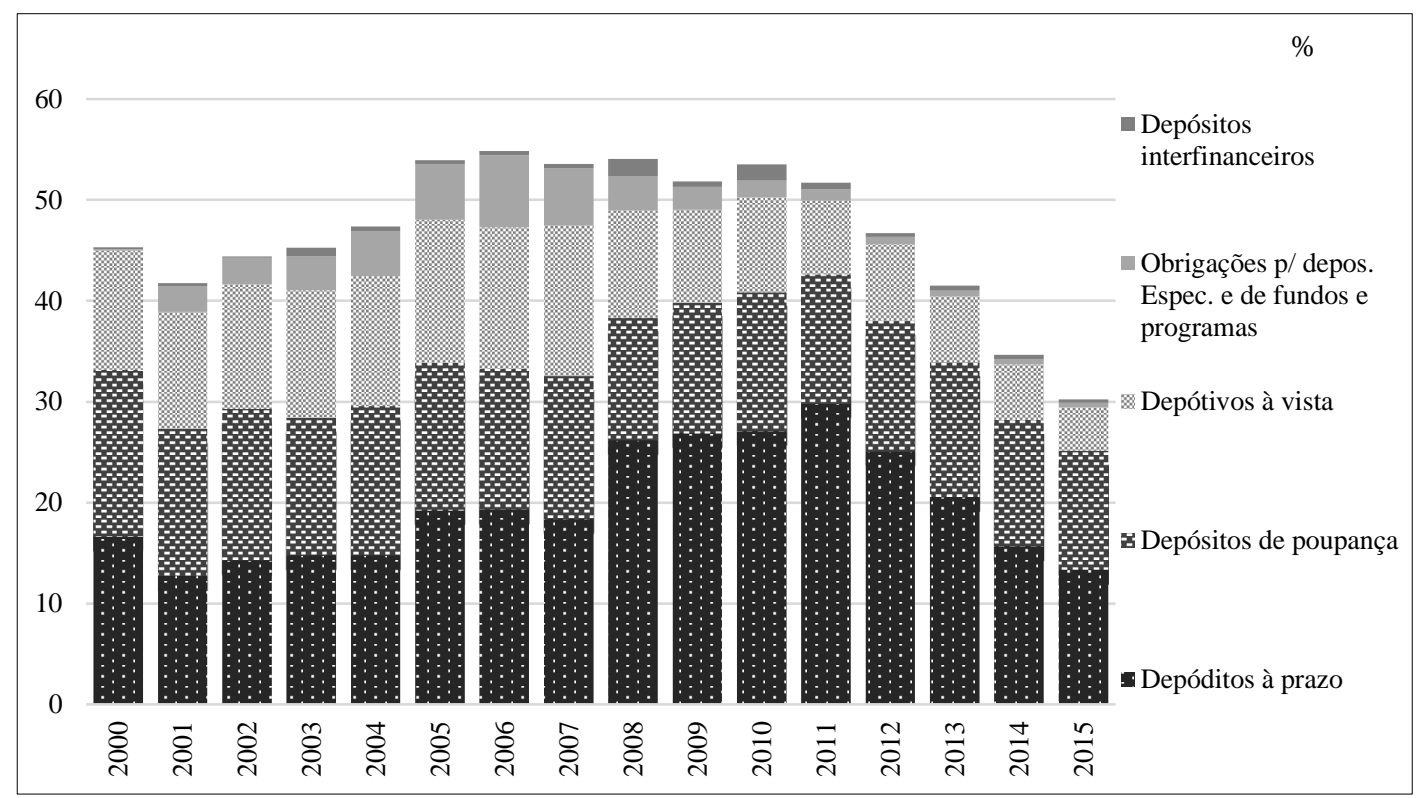

Fonte: BCB.

Na comparação com a mesma conta do passivo da Caixa, verifica-se presença bem menos relevante de recursos provenientes de fundos e programas sociais, ainda que os recursos do Fundo Constitucional do Centro-Oeste - FCO e do Fundo da Marinha Mercante representem parte expressiva dos valores registrados sob a conta. Em operação análoga à executada pela

(16) Os dados constantes nos relatórios de administração do BB apresentam informações separadas para os depósitos de cada um dos fundos apenas a partir de 2008. 
Caixa com parte dos repasses do FGTS, a partir de 2005, os recursos disponibilizados pelo FCO para operacionalização pelo BB receberam tratamento de dívida subordinada elegível a capital, o que possibilitou que fossem considerados como capital de nível II, contribuindo para aumentar a capacidade de alavancagem do Banco, nos marcos regulatórios do Acordo de Basiléia. O crescimento do montante destes recursos foi de $128,6 \%$, em termos reais, entre 2003 e 2015, quando chegou a R \$22,9 bilhões (ver Gráfico 14).

Gráfico 14

Montante de recursos do FCO e participação no total do passivo circulante exigível - BB

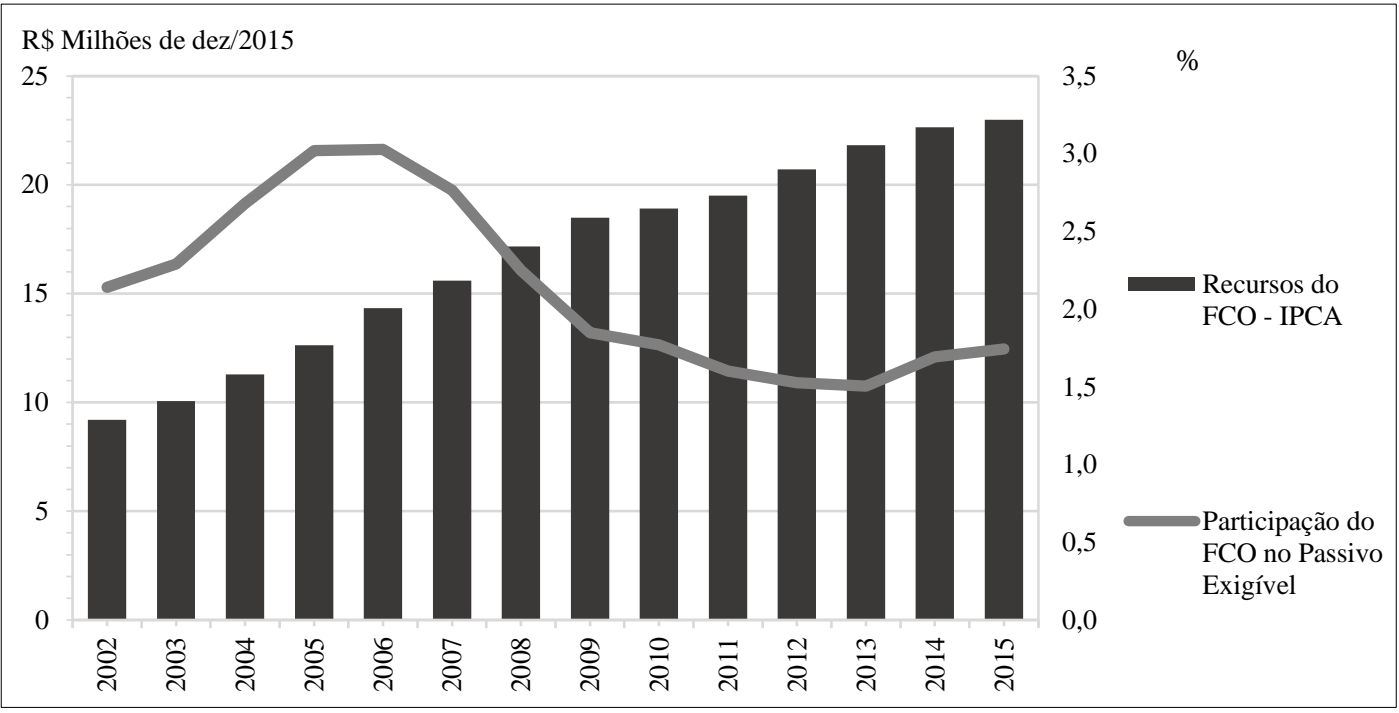

Fonte: Relatórios De Administração - Banco do Brasil (2003 a 2015). Valores inflacionados pelo IPCA.

Apesar disto, sua presença no total do passivo oscilou entre 1,5\% e 3,0\%, sendo os anos de 2005 e 2006 aqueles de maior participação (ambos com 3,0\%). Ainda que de tamanho menor que o FGTS, é preciso lembrar que se trata de um fundo regional, com utilização exclusiva em operações no Centro-Oeste. Em 2015 os recursos do FCO cobriam cerca de $28,5 \%$ das operações realizadas pelo $\mathrm{BB}$ na região ${ }^{17}$.

As contas que apresentaram maior crescimento em sua participação no período foram, recursos de aceites cambiais, letras imobiliárias e hipotecárias, debêntures e similares, obrigações por operações compromissadas e instrumentos financeiros derivativos (Gráfico 15). O crescimento da primeira destas contas, que somente passou a existir a partir de 2010, foi bastante representativo, atingindo $\mathrm{R} \$ 155,0$ bilhões em volume de recursos em 2015, isto é, num período de apenas cinco anos. O ritmo de expansão acelerado desta rubrica fez dessa a maior expansão, em termos de porcentagem do total, do PCE (12,1 p.p.).

(17) Proxy a partir da razão entre os recursos do FCO discriminados nas notas técnicas do relatório de administração do BB, em 2015, e a carteira de crédito ativa do Banco, na região Centro-Oeste, em dezembro de 2015, conforme dados disponíveis no IF.Data do BCB. 
Gráfico 15

Participação dos recursos de aceites cambiais, letras imobiliárias e hipotecárias, debentures e similares no Passivo circulante exigível, por tipo - BB

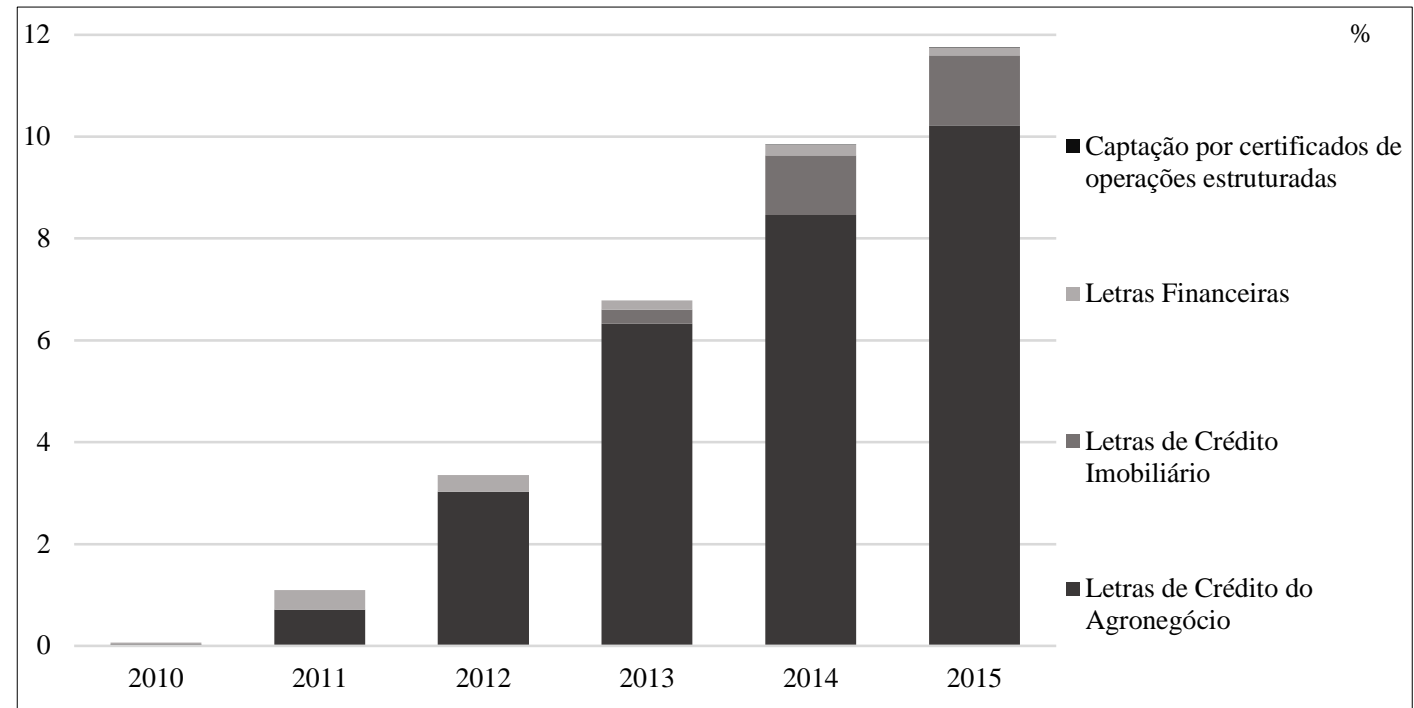

Fonte: Relatórios De Administração - Banco do Brasil (2011 a 2015) e BCB.

Para informações mais detalhadas na rubrica recursos de letras imobiliárias, hipotecarias, de credito e similares sobre os tipos de letras lançadas, recorremos aos relatórios de administração do $\mathrm{BB}$, que evidenciam a presença marcante das Letras de Crédito do Agronegócio (LCA), em comparação com as demais - Letras de Crédito Imobiliário (LCI), Letras Financeiras e Certificados de Operações Estruturadas. A participação das LCAs (ver Gráfico 15) apresentou crescimento nos cinco anos posteriores ao seu lançamento, no ano de 2010 , chegando a $\mathrm{R} \$ 134,8$ bilhões em 2015 . Este montante representava $86,9 \%$ da conta recursos de aceites cambiais, letras imobiliárias e hipotecárias, debêntures e similares e 10,2\% do total do PCE, em 2015, afirmando-se como instrumento de importância crescente para as estratégias recentes de funding do Banco.

Para as outras duas contas que tiveram crescimento relevante na participação no total do PCE, as informações constantes tanto na série Balancetes quanto nos relatórios de administração do BB apresentam menor nível de detalhamento. Nas obrigações por operações compromissadas, conta que passou a rivalizar em magnitude com os depósitos totais, representando 26,3\% do total do PCE em 2015, houve aumento de 6,7 p.p. em participação.

$\mathrm{O}$ crescimento da conta instrumentos financeiros derivativos foi o mais representativo dentre todas as contas do passivo do BB, registrando aumento real de 5.593,2\%, entre 2003 e 2015, concentrada especialmente nos anos de 2006 (taxa interanual real de crescimento de $529,5 \%)$ e $2013(1,067,0 \%)$. Com isso, a participação desta conta no total do passivo avançou, no período, de $0,2 \%$ para $4,1 \%$. 
Gráfico 16

Participação dos repasses de instituições oficiais, no passivo circulante exigível, por instituição - BB

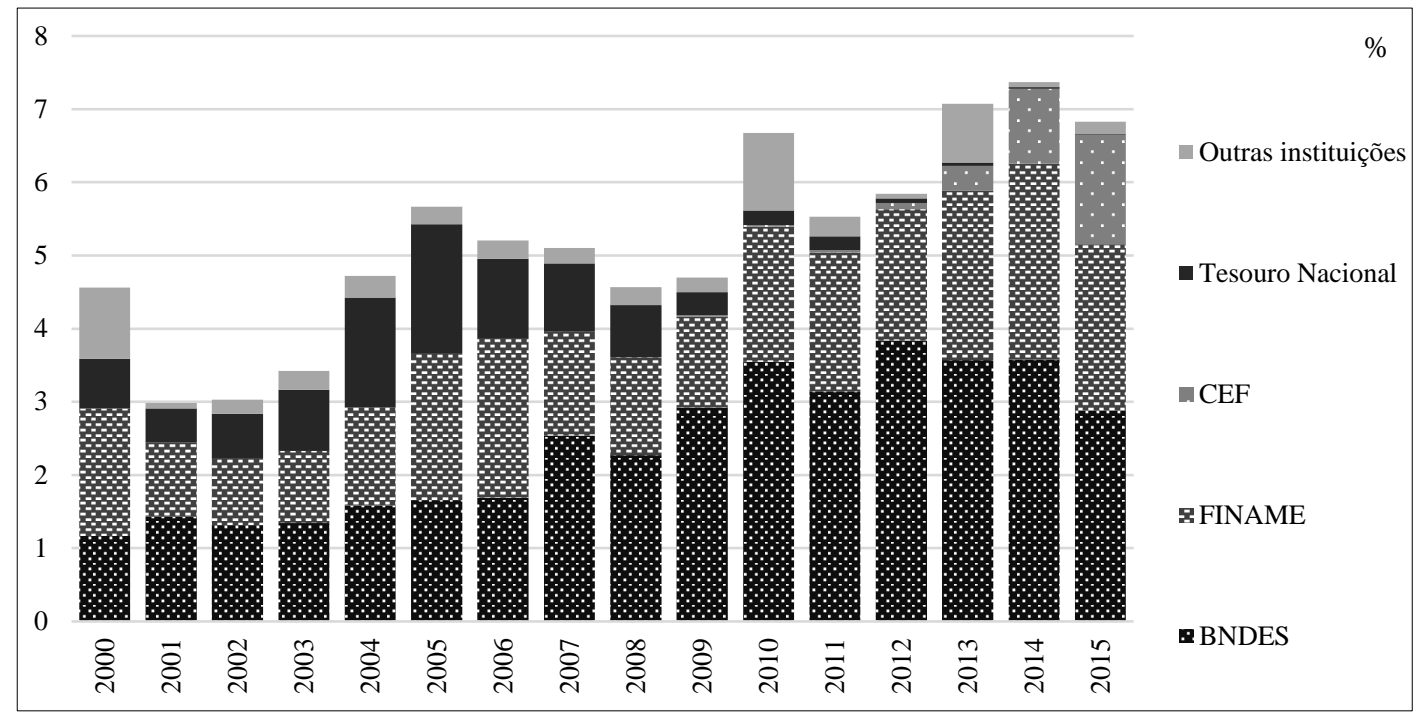

Fonte: Relatórios De Administração - Banco do Brasil (2001 a 2015)

Ainda, é preciso notar o papel destacado de obrigações por empréstimos e repasses, que representava, em 2015, 14,2\% do total de seu PCE. A conta apresenta substantivas oscilações, resultantes da dinâmica praticamente inversa dos dois principais itens que a compõem: 1) repasses do país - instituições oficiais, que registrou crescimento real de 502,5\%, entre 2003 e 2015, aumentando a participação de 3,7\% para 7,0\% no total do passível exigível; e 2) empréstimos do exterior, item que registrou perda de participação de 4,3 p.p. nas contas, caindo de $9,0 \%$ para $4,7 \%$, apesar de também ter registrado crescimento real de $65,1 \%$, bem mais modesto do que a rubrica anterior (Gráfico 16).

Já o crescimento observado nos Repasses do País - Instituições Oficiais, reflete fundamentalmente a expansão dos repasses do BNDES e do Finame para o BB. Os repasses do BNDES crescem em importância no conjunto das contas passivas do Banco a partir de 2007, quando sua participação sobre o PCE total passa de 1,7\% para 2,5\%, aumentando progressivamente, até atingir seu ponto máximo em 2014 (3,6\%). A presença cada vez maior de recursos originados no BNDES nos repasses do Banco reflete a importância do último como agente financeiro do primeiro.

Ainda sobre recursos de instituições oficiais, cabe destacar a entrada da Caixa como agente repassador para o BB, a partir de 2009, cujos repasses atingiram montante de $\mathrm{R} \$ 19,7$ bilhões, em 2015, cifra correspondente a $21,9 \%$ do total dos repasses de instituições oficiais e 1,5\% do total do PCE da instituição. Conjuntamente, os repasses do BNDES e do Finame, que eram relativamente modestos no começo do período analisado, registraram aumento gradual ao longo da série, ultrapassando a participação de outros recursos parafiscais também importantes para as estratégias de funding do Banco do Brasil, como FAT, Funproger e o próprio FCO. 
Se, para a Caixa, as operações vinculadas a fundos de poupança compulsória foram fundamentais para garantir a expansão do conjunto das operações, no caso do BB, ganharam espaço as operações de repasses assentadas em recursos do BNDES e de financiamento imobiliário - neste caso, para o qual foram utilizados, principalmente, recursos próprios. Assim, conclui-se que as operações de crédito do BB estão concentradas, como era de se esperar em empréstimos e financiamentos rurais e agroindustriais, ainda que os últimos tenham perdido participação para os primeiros, ao longo do período analisado. No entanto, destaca-se o crescimento das operações de Financiamentos e financiamentos imobiliários, que registraram taxas elevadas de crescimento real entre 2003 e 2015, no primeiro caso, e a partir de sua implantação, em 2008, no segundo. Ainda, no auge da crise financeira internacional, o aumento nas de operações de crédito foi basicamente concentrado em empréstimos, ou seja, crédito para consumo, com desaceleração nos financiamentos e nos financiamentos rurais $e$ agroindustriais. Pode-se argumentar que a perda de participação de empréstimos $e$ financiamentos rurais e agroindustriais para financiamentos e financiamentos imobiliários parece estar calcada, no primeiro caso, nos recursos de Repasse do BNDES, e no segundo caso, em recursos próprios. Assim, durante o período observa-se importante diversificação nas operações de crédito, por modalidade. Como contrapartida, ocorreu diversificação também nas fontes de recursos da instituição.

\section{Banco Nacional de Desenvolvimento Econômico e Social - BNDES}

As operações de crédito do BNDES, no período entre 2003 e 2015, subiram 237\%, em termos reais. Somente após entre junho de 2008 e dezembro de 2015, o total das operações do Banco cresceu $200 \%$, em termos reais. Considerando-se o perfil de suas operações ativa, o papel central do BNDES na expansão das operações de crédito dos BPFs se reflete de maneira distinta sobre suas contas ativas, quando comparado aos casos da Caixa e do BB. Isto porque o movimento analisado nas seções anteriores, de expansão da participação das operações de crédito no conjunto das contas ativas, não se expressa de maneira tão intensa no BNDES. Em linhas gerais, a análise acerca da posição patrimonial do BNDES deve levar em conta suas especificidades, dado sua característica de banco de desenvolvimento.

No que tange às posições ativas do BNDES, destaca-se a concentração em duas contas - operações de crédito e relações interfinanceiras, que refletem as distintas formas de atuação do Banco no mercado creditício, por meio de operações de primeiro e segundo pisos. Assim, são computados na conta de operações de crédito apenas os financiamentos contratados diretamente entre o BNDES e o tomador final (primeiro piso), sendo as operações realizadas por meio de repasses a outras instituições financeiras (segundo piso) registradas na conta de relações interfinanceiras. Os valores desta rubrica são, desta forma, a contraparte da conta obrigações por empréstimos e repasses, no passivo dos bancos repassadores de recursos do BNDES, como já apontado nas análises da Caixa e do BB. Ao longo do período analisado, a soma das participações destas duas contas no conjunto das posições ativas do BNDES oscilou entre o mínimo de 70,5\%, em 2012, e o máximo de 84,9\%, em 2003, refletindo a centralidade da atividade creditícia no âmbito de sua atuação. 
Gráfico 17

Composição do Ativo - BNDES

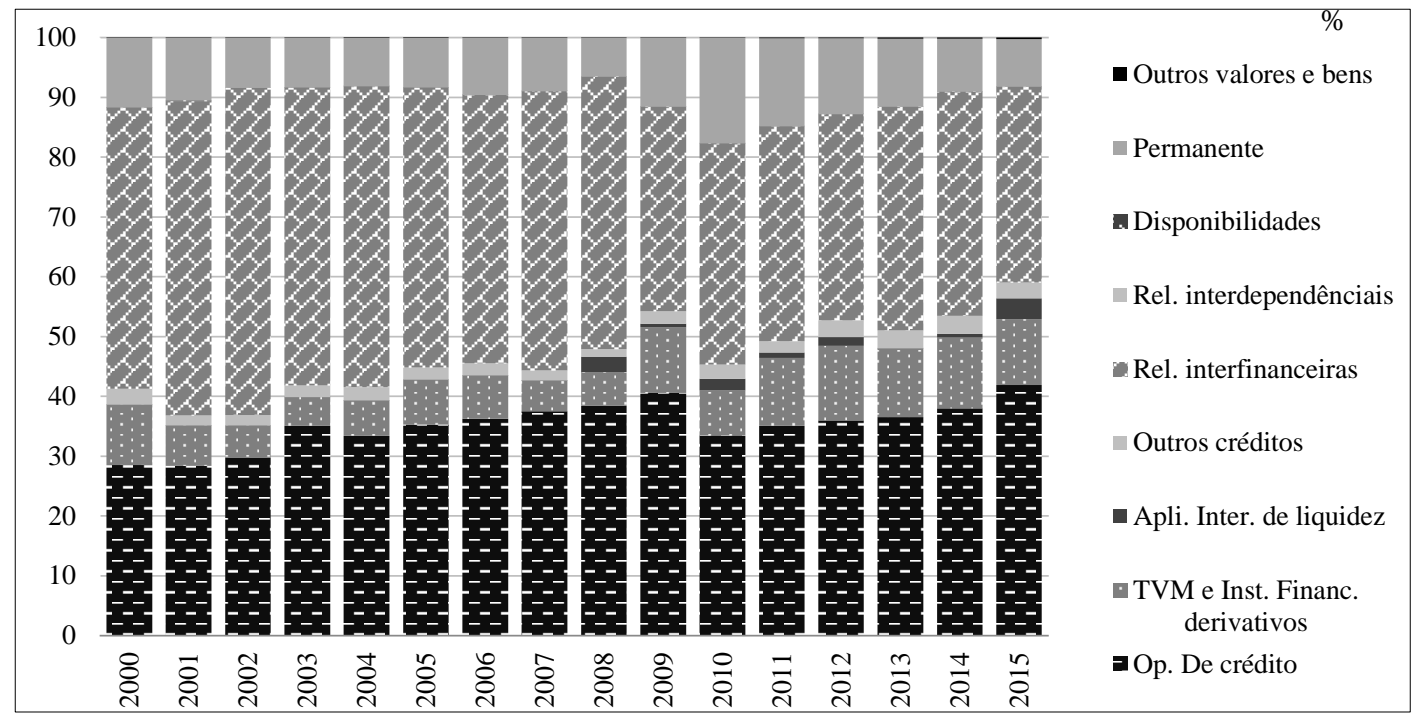

Fonte: BCB.

Gráfico 18

Operações de crédito e relações interfinanceiras - BNDES

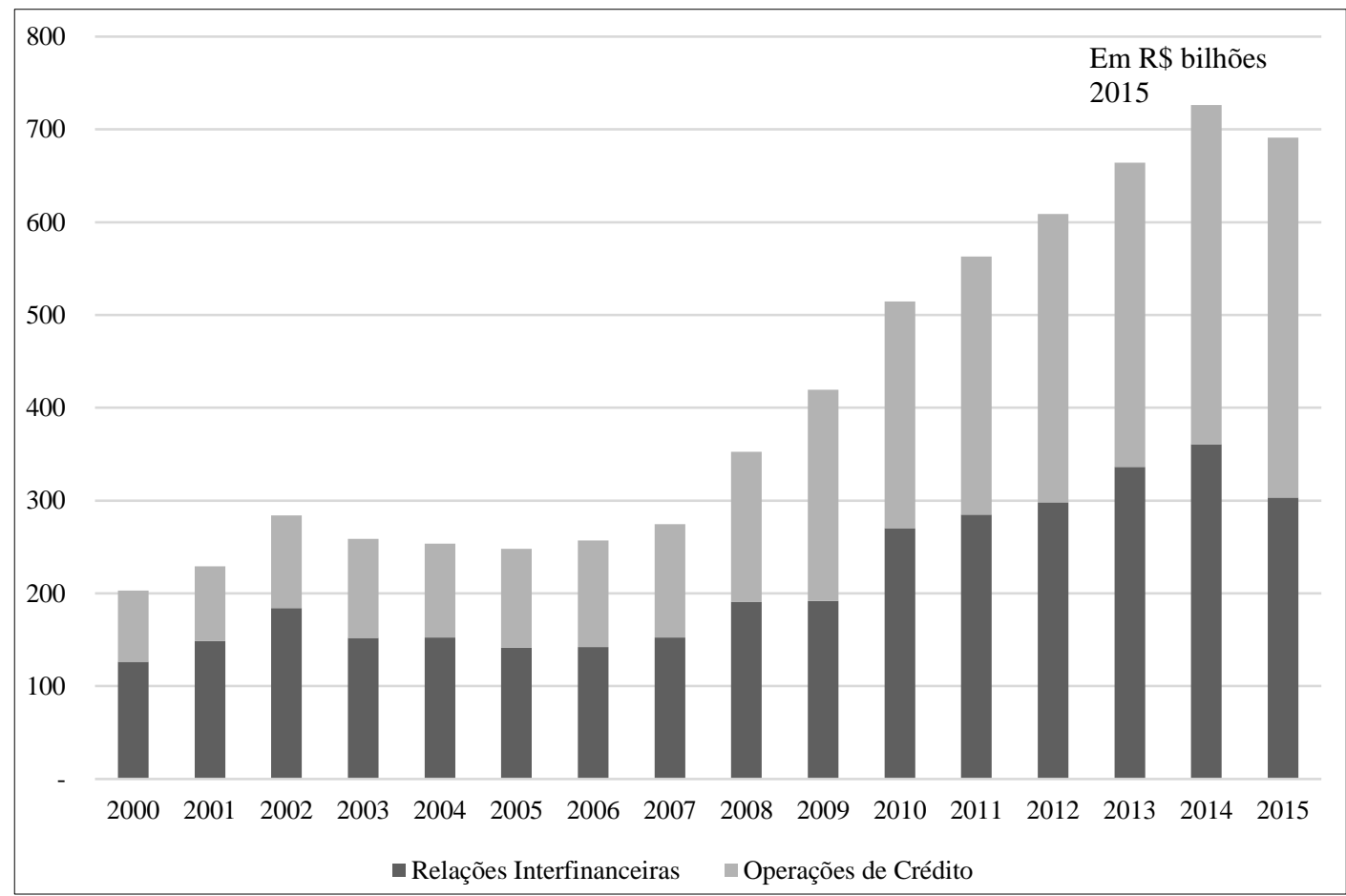


As outras duas contas relevantes no conjunto das operações ativas do BNDES são títulos e valores mobiliários e instrumentos financeiros derivativos, cuja participação oscila no período entre o ponto mínimo de 4,8\%, em 2003, e o máximo de $12,5 \%$, em 2012, e a conta permanente, com mínimo de 6,5\%, em 2008, e máximo de 17,6\%, em 2010. Enquanto a participação de TVM no conjunto dos ativos do BNDES é significativamente menor do que aquela observada para a Caixa e o $\mathrm{BB}$, a conta permanente tem representatividade muito superior, uma vez que raramente supera a marca de 5,0\% de participação entre as contas ativas dos PBFs comerciais. A maior preponderância desta conta no caso do BNDES é também reflexo de suas estratégias de atuação, já que é composta, fundamentalmente, pelo item Participação em Coligadas, notadamente a BNDES Participações S.A. - BNDESPAR, empresa que opera por meio de subscrição de ações e debêntures conversíveis, e a Agência Especial de Financiamento Industrial (Finame) ${ }^{18}$, empresa que concede financiamentos para compra de máquinas e equipamentos. Outros créditos e aplicações interfinanceiras de liquidez têm presença menos significativa, a despeito do crescimento importante da participação da última, a partir de 2013, em função do aumento das aplicações do BNDES em operações compromissadas.

As contas de operações de crédito e relações interfinanceiras (Gráfico 18), pela centralidade que ocupam dentre as posições ativas do BNDES merecem descrição mais detalhada ${ }^{19}$. Entre 2003 e 2015, ambas registraram taxas de crescimento real elevadas, ainda que com variação mais acentuada em operações de crédito $(263,1 \%$, no período) do que em relações interfinanceiras $(99,6 \%)$. Este movimento atesta para um aspecto importante, acerca das estratégias de atuação do BNDES. A ampliação das operações foi realizada principalmente por meio de operações diretas, nas quais o risco é da própria instituição. Como resultado, ao final do período, a conta operações de crédito havia aumentado 6,8 p.p. na participação do conjunto das contas ativas do BNDES, tornando-se a principal rubrica em 2015, com 41,9\% do total, enquanto a conta relações interfinanceiras havia caído 17,1 p.p., encerrando o período analisado com $32,7 \%$ de participação.

Considerando-se o período contemplado, a evolução destas duas contas é reveladora das diferentes estratégias adotadas pelo BNDES, em conjunturas distintas. O primeiro período, entre o início do ano 2000 e final de 2002, que representa o fechamento do ciclo de ajustes dos BPFs, foi para o BNDES bastante diferente do que pode ser observado no caso da Caixa, já que houve, em todos estes anos, taxas de crescimento real das operações de crédito e da conta de relações interfinanceiras, ambas com registros de variação de elevada magnitude.

(18) O movimento atípico observado na conta Permanente para o ano de 2010, com crescimento de R $\$ 43,4$ bilhões para $\mathrm{R} \$ 91,5$ bilhões e consequente aumento de $11,5 \%$ para 17,6\% de participação no conjunto das contas ativas do BNDES, reflete incremento de $\mathrm{R} \$ 36,9$ bilhões em 2009 para $\mathrm{R} \$ 84,9$ bilhões em 2010 no valor contábil do investimento do BNDES na BNDESPAR. Não localizamos nos relatórios de administração de nenhuma das duas instituições, informações detalhadas a respeito desta operação.

(19) No caso do BNDES, este detalhamento por nicho de mercado não é relevante, visto que todas as operações do Banco são registradas sob a mesma rubrica "Financiamentos". O aspecto importante a explorar são as distintas dinâmicas de atuação em primeiro (operações de crédito) e segundo (relações interfinanceiras) piso. 
Notadamente entre dezembro de 2001 e o mesmo mês de 2002, a conta operações de crédito obteve crescimento real de $24,3 \%$, enquanto no caso das relações interfinanceiras foi de $23,8 \%$.

O período posterior, entre 2003 e a eclosão da crise financeira internacional, em 2007/2008, momento em que tanto Caixa quanto BB tiveram taxas de crescimento moderadas, porém constantes, foi muito mais modesto, no caso do BNDES, marcando também o primeiro ensaio de reversão de sua estratégia de atuação indireta, já que a conta operações de crédito acumulou variação real de $14,4 \%$, ao longo deste período, ao passo que a conta relações interfinanceiras teve variação real praticamente nula $(0,3 \%)$.

Com a deflagração da crise global e a utilização, no Brasil, dos BPFs para sustentar a oferta de crédito, verificou-se forte crescimento dessas operações, com alta real anual de 32,0\% em 2007 e 41,1\% em 2008. No que importa ao movimento da conta relações interfinanceiras, observa-se variação real mais modesta em 2007, de 25,4\%, e praticamente nula em 2008, de $0,4 \%$, o que evidencia que a estratégia de ativação do crédito público, ocorreu com preponderância de operações diretas, de primeiro piso. É razoável supor, a partir da análise dos dados, que a desaceleração da taxa de crescimento da conta relações interfinanceiras em 2008 refletiu o aumento da aversão ao risco por parte das instituições financeiras repassadoras de recursos do BNDES, sobretudo as privadas. Nesta conjuntura, o aumento das operações diretas, por parte do Banco, teria correspondido à alternativa encontrada para fazer frente à retração dos bancos privados do mercado creditício.

A fase seguinte, entre 2009 e 2010 , representa período de desaceleração, em relação ao período anterior, no que toca à conta operações de crédito. No entanto, se considerarmos a conta relações interfinanceiras, o quadro aparece de modo totalmente distinto, visto que as operações registradas sob esta rubrica aumentaram 40,8\% em 2010, variação real mais acentuada em todo o período analisado. Interessante observar que este período marca o início dos aportes do Tesouro Nacional ao BNDES, sendo o ano de 2009 aquele em que houve o repasse de maior magnitude ( $\mathrm{R} \$ 100$ bilhões), além de ser também o ano em que foi implementado o Programa de Sustentação do Investimento - $\mathrm{PSI}^{20}$. Isso evidencia a necessidade de prospectar, nas análises sobre o BNDES, não apenas as operações de crédito diretas, mas, sobretudo, a dinâmica conjunta das operações em primeiro e segundo pisos. A desaceleração identificada nas operações de crédito do BNDES para este período oculta, de certa forma, o movimento de reversão na estratégia de atuação do Banco, com intensificação das atividades de segundo piso.

(20) Com o objetivo de promover a sustentação dos investimentos produtivos, sobretudo no setor industrial, o PSI funcionava por meio da utilização de recursos orçamentários do Tesouro Nacional para equalização das taxas de juros dos empréstimos do BNDES, permitindo ao Banco emprestar em determinadas linhas, com taxas inferiores a seu custo de captação. O programa, encerrado em 2015, não deve ser confundido com a política de repasses, cuja motivação era aumentar a oferta de crédito de longo prazo, por meio da injeção de recursos fiscais no BNDES. 
No período que se seguiu, entre 2011 e 2014, ambas as contas registraram taxas de crescimento significativas, ainda que bem inferiores às verificadas entre 2007 e 2008. Novamente, a conta operações de crédito assumiu papel destacado na expansão da atividade creditícia do BNDES, acumulando variação real de 49,7\%, ao passo que a conta relações interfinanceiras teve crescimento menos intenso, de 33,5\%. Finalmente, no ano de 2015, a aversão ao risco das instituições bancárias privadas parece ter, novamente, se refletido sobre a conta de relações interfinanceiras do BNDES, que registrou variação real negativa de 15,9\%, enquanto a conta operações de crédito continuou sua trajetória de crescimento, ainda que em patamar mais modesto $(6,0 \%)$.

Gráfico 19

Composição do passivo - BNDES

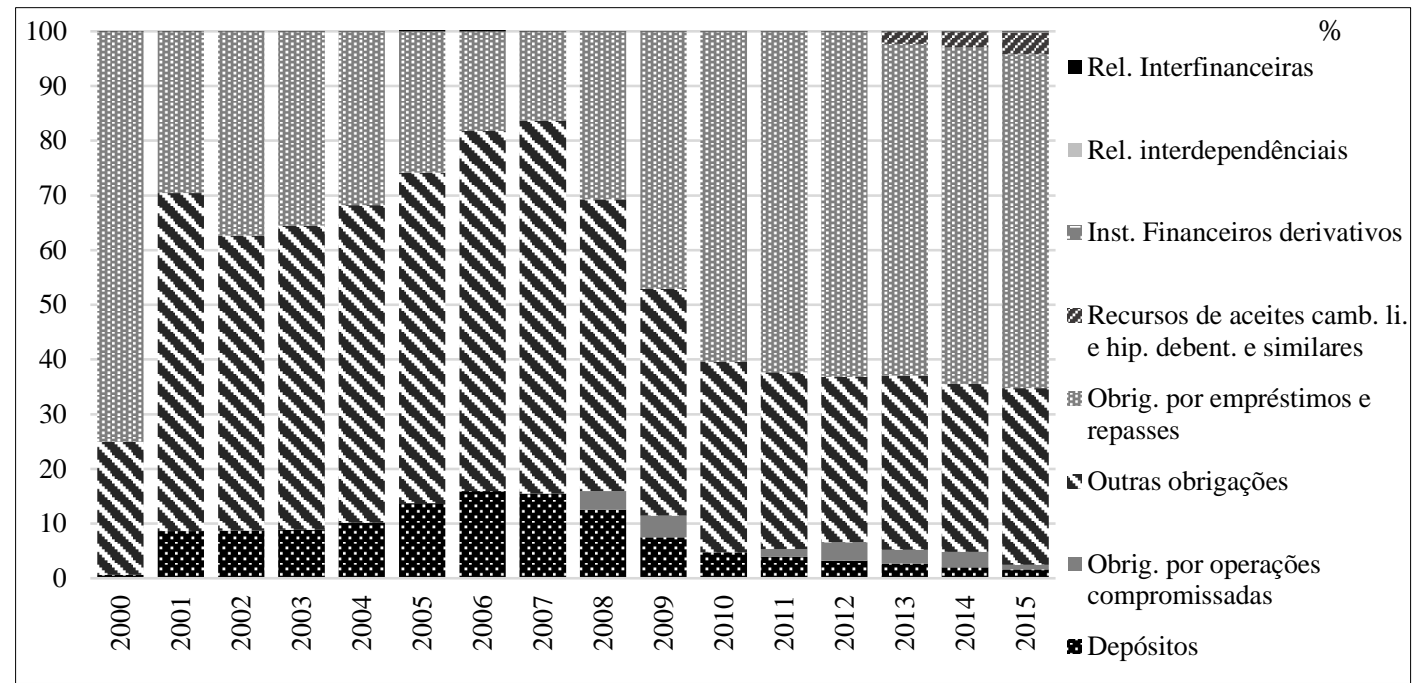

Fonte: BCB.

A análise da evolução das contas passivas do BNDES possibilita melhor entendimento acerca das estratégias de obtenção de funding que permitiram expansão de sua oferta de crédito. A primeira vista, a composição das contas, em termos de participação no total do passivo circulante exigível, evidencia que o padrão de financiamento das operações é significativamente mais concentrado do que o observado para Caixa e BB, o que reflete sua especificidade de banco de desenvolvimento. Isto porque, além de não receber depósitos do público, a gestão de seu passivo deve ser particularmente cuidadosa quanto aos prazos, haja vista a concentração de sua oferta de crédito em prazos de maturação mais longa. As especificidades da atuação de um banco de desenvolvimento impõem algumas restrições em relação ao tipo de funding adequado, de modo que a estrutura das posições passivas do BNDES pode ser considerada como muito mais simplificada do que as da Caixa e do BB, que podem se financiar de diversas formas. 
Dentre as principais diferenças, ressalta-se a conta de Depósitos, que sempre esteve em patamar baixo, em termos de participação e magnitude, no PCE do BNDES, ainda que tenha ganho relativo espaço até a eclosão da crise financeira. A principal explicação para este aumento na participação nessa conta, entre 2003 e 2007, quando chegou a 15,5\%, é o movimento do subitem Obrigações por depósitos especiais e de fundos e programas, rubrica onde são registrados os valores depositados pelo Fundo de Amparo ao Trabalhador (FAT), que superam o mínimo constitucional de $40 \%$ (nota 20). Outras contas são obrigações por operações compromissadas, com participação incipiente, nunca superior a 4,0\%, e decrescente; relações interfinanceiras, nunca superior a $0,1 \%$, e recursos de aceites cambiais, letras imobiliárias e hipotecárias, debêntures e similares, reflexo sobretudo do lançamento de títulos no exterior, cuja participação, apesar de ainda pequena (3,9\% em 2015), vem ganhando espaço desde seu surgimento, em 2013.

Gráfico 20

Evolução da participação e do montante de recursos do FAT Constitucional - BNDES

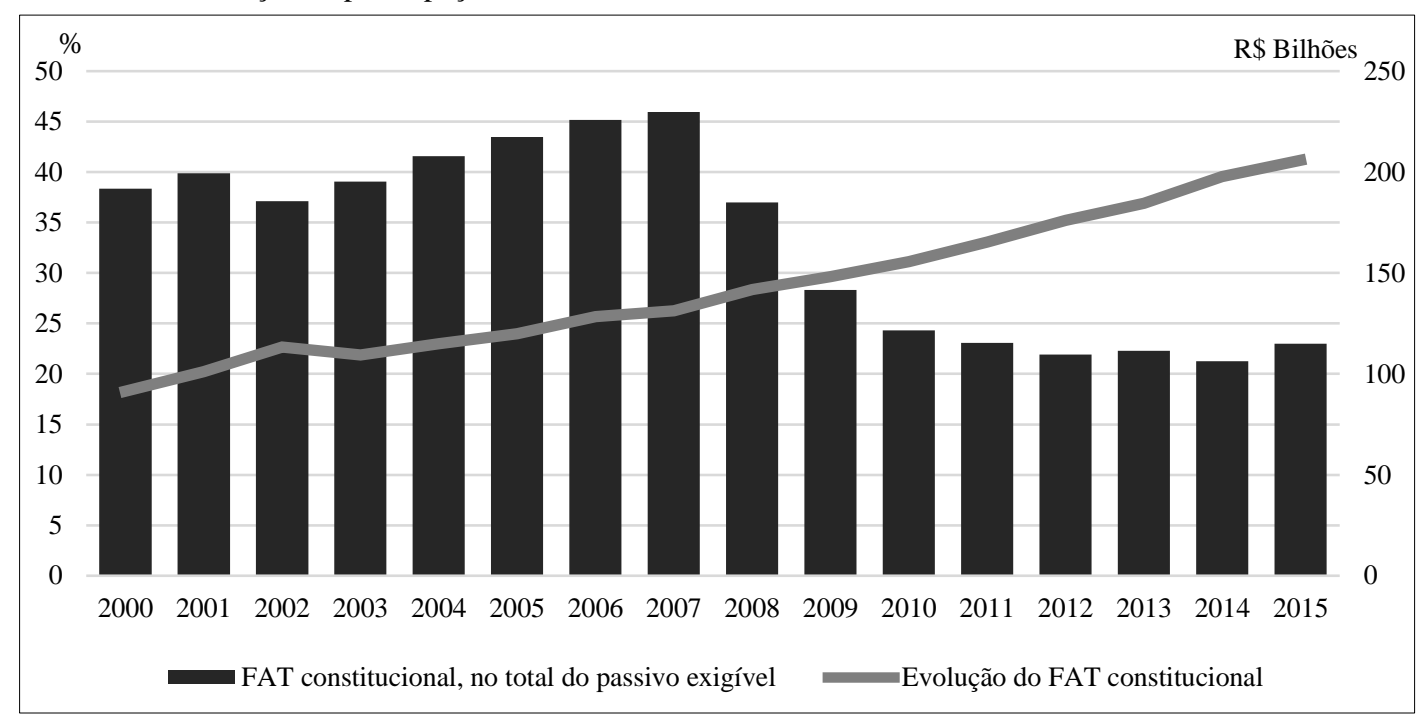

Fonte: Demonstrações Financeiras - BNDES (2000 até 2016).

A estrutura das posições passivas do BNDES também pode ser considerada mais simplificada do que as da Caixa e do BB, estando concentradas basicamente em duas rubricas - operações por empréstimos e repasses e outras obrigações. Somadas, estas contas nunca estiveram em patamar inferior a $84,0 \%$ do passivo do BNDES, tendo chegado ao ponto máximo de $99,4 \%$ no ano 2000. Há, no entanto, importante modificação em sua posição relativa, tendo como ponto de inflexão, o ano de $2008^{21}$. Entre 2001 e 2007, verificou-se crescente participação de outras obrigações, que segue como a principal rubrica nas contas passivas do

(21) A análise a seguir não considera o ano 2000, tendo em vista sua atipicidade. Até aquele ano, os recursos originados no FAT, ainda eram contabilizados na rubrica Repasses no País - Instituições Oficiais. 
BNDES. Após ligeira queda entre 2001 e 2002, a participação dessa conta aumentou de 53,9\% para $68,2 \%$ em 2007, seu ponto máximo, para cair progressivamente ao patamar de $34,8 \%$ em 2010, onde se mantém praticamente estável até 2015. Em comparação, obrigações por empréstimos e repasses, que perdeu participação entre 2001 e 2007, cresceu entre este ano e 2010 , passando de $16,3 \%$ para $60,4 \%$, patamar em que se manteve até 2015 . A despeito de ambas as contas abrangerem diversos subitens, a explicação para o movimento observado pode ser reduzida a duas rubricas - os recursos originados no FAT, registrados sob o nome FAT Constitucional, na conta outras obrigações; e os Repasses do Tesouro Nacional, contabilizados em obrigações por empréstimos e repasses (Gráfico 20).

Compostos a partir da arrecadação de contribuições para o PIS e PASEP, os recursos do FAT têm como finalidade custear a concessão de benefícios de Seguro Desemprego e Abono Salarial, tendo relação estreita com o BNDES desde a inclusão na Constituição Federal de dispositivo (art. 239) que destina, pelo menos, $40 \%$ do valor arrecadado pelo fundo para o financiamento, por meio do Banco, de projetos com impacto sobre a criação de postos de trabalho ${ }^{22}$. Em 2015, o montante de recursos do FAT à disposição do BNDES atingiu a cifra de $\mathrm{R} \$ 205,8$ bilhões, constituindo-se numa das mais importantes fontes de recursos para o financiamento de longo prazo no Brasil ${ }^{23}$.

Uma vez que está atrelado às contribuições para o PIS e o PASEP, cuja base de arrecadação são as folhas de pagamento dos setores privado e público, os recursos do FAT são fortemente influenciados pelo desempenho do mercado de trabalho formal. Assim, a evolução do FAT Constitucional no passivo do $\mathrm{BNDES}^{24}$, entre 2003 e 2015, registrou taxa de crescimento real sistematicamente progressiva, acumulando variação de $88,1 \%$, em consonância com os movimentos de aumento da população ocupada na força de trabalho e da taxa de formalização dos postos de trabalho.

Apesar deste robusto crescimento, houve perda de participação relativa da conta FAT Constitucional no conjunto do PCE do BNDES, em função do crescimento mais acelerado da conta obrigações por empréstimos e repasses, ou mais precisamente, das operações de repasse do Tesouro Nacional. De fato, após crescimento de 6,9 p.p. entre 2003 e 2007, quando atingiu o máximo de 46,0\% de participação no total do PCE, os recursos do FAT decresceram 21,6 p.p. entre 2007 e 2010, passando a oscilar em torno do novo patamar de 24,3\%, até 2015.

(22) Recursos que não sejam aplicados nos programas de Seguro Desemprego e Abono Salarial devem ser depositados junto a instituições financeiras públicas, sob a rubrica Depósitos Especiais, como já visto na análise do BB. É importante observar que é permitido ao fundo aplicar mais do que o mínimo obrigatório de $40 \%$ no BNDES, registrando-se o valor que ultrapassa o mínimo também sob a rubrica Depósitos Especiais.

(23) Remunerados à Taxa de Juros de Longo Prazo - TJLP, os recursos do FAT possibilitam ao BNDES não apenas funding de longo prazo, mas também barato, permitindo a concessão de crédito a taxas inferiores à Selic.

(24) A rubrica FAT Constitucional, subitem da conta Outras Obrigações, não está discriminada na série Balancetes do Banco Central. Para a composição destes dados, foram utilizadas informações dos Relatórios de Administração e Demonstrações Financeiras do BNDES, entre os anos 2000 e 2015. 
Gráfico 21

Participação dos empréstimos e repasses no passivo circulante exigível, por modalidade - BNDES

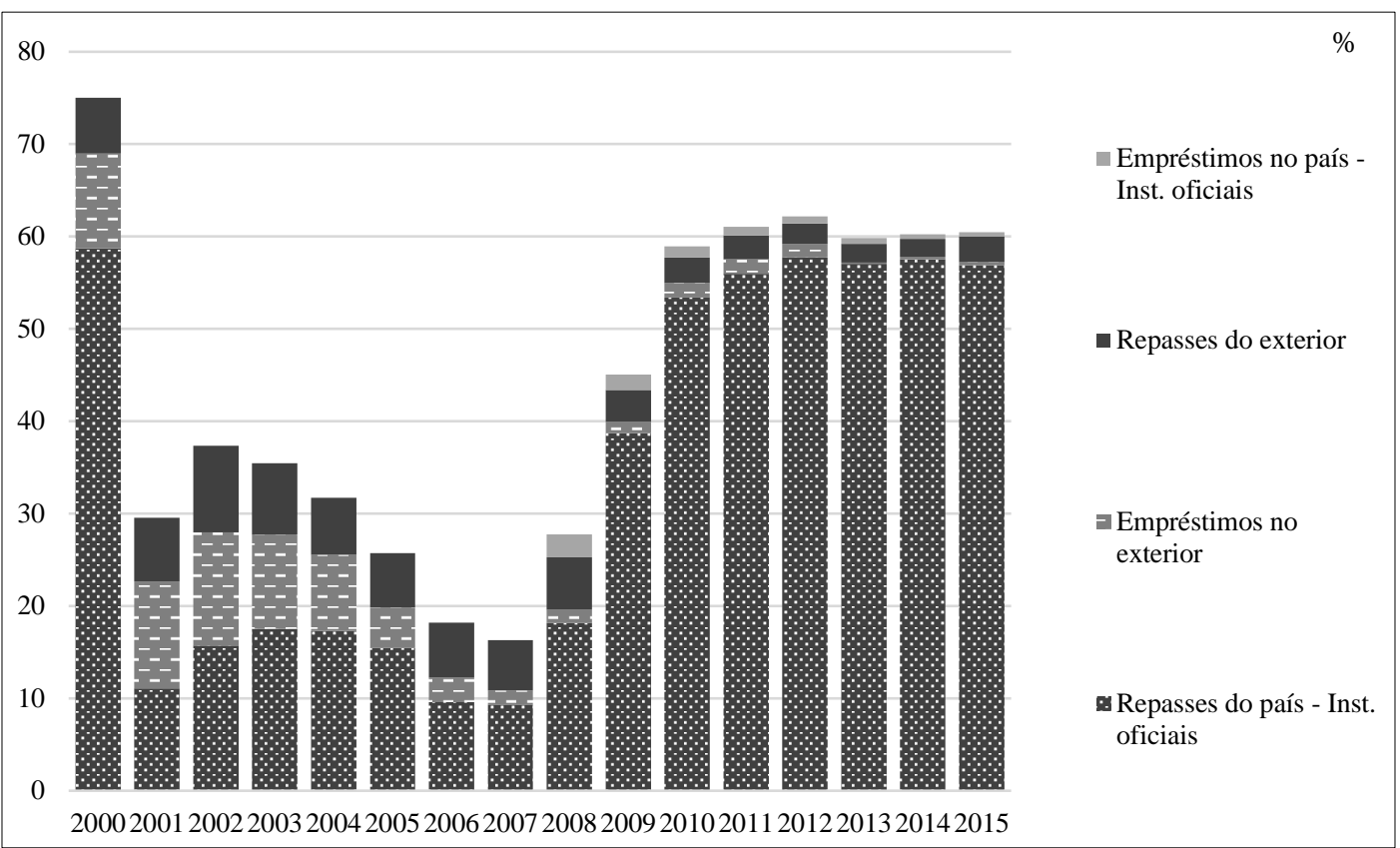

Fonte: BCB.

A inversão na posição relativa destas duas contas deve-se ao crescimento mais do que proporcional de obrigações por empréstimos e repasses, notadamente pelo item Repasses do País - Instituições Oficiais, onde estão contabilizados os repasses do Tesouro Nacional (Gráfico 21). Com o crescimento deste item, outras modalidades de repasses e de empréstimos, que também tinham relativa importância no conjunto das operações passivas do BNDES, perderam espaço, sobretudo repasses do exterior, cuja participação se reduziu de $7,7 \% \mathrm{em}$ 2003 para 2,8\% em 2015, e empréstimos do exterior, com queda de $10,2 \%$ para $0,3 \%$. No caso dos empréstimos do exterior houve, ao longo deste período, não apenas perda de participação relativa no PCE do Banco, como variação negativa real de 90,3\%.

Considerando-se apenas a composição da conta Repasses do País - Instituições Oficiais, que representa, isoladamente, o maior ganho de participação no conjunto do passivo do BNDES, no período, é possível observar incrementos consecutivos entre os anos de 2008 e 2015, refletindo os aportes do Tesouro Nacional ao Banco - $\mathrm{R} \$ 22,5$ bilhões em 2008, $\mathrm{R} \$$ 105,0 bilhões em 2009, R \$ 82,3 bilhões em 2010, R \$ 50,2 bilhões em 2011, R \$ 55,0 bilhões em 2012, R\$ 41,0 bilhões em 2013 e R \$ 60,0 bilhões em 2014, totalizando R \$ 416,1 bilhões ${ }^{25}$.

(25) A soma dos aportes realizados entre 2008 e 2015 registra valor inferior aos R 523 bilhões referentes ao passivo do BNDES junto ao Tesouro Nacional em 2015, cifra amplamente noticiada. O motivo para a divergência nos valores são as incidências de juros e correção monetária, sobre o montante devido. No que importa às taxas de juros cobradas por estes repasses, a despeito da maioria estar referida à TJLP, há casos bastante variados: Selic, dólar mais taxa fixa, taxas fixas de diferentes valores, entre outros. A lista detalhada destas operações pode ser encontrada em: http://www.bndes.gov.br/wps/wcm/connect/site/920f58d6-6a67-46ad-91d7-e90dac1201ed/2015 4T_captacoes tesouro.pdf. 
Estes recursos, disponibilizados inicialmente na esteira da crise financeira global tiveram o intuito de calçar a atuação contracíclica do BNDES e posteriormente potencializar sua atuação como agente de desenvolvimento.

Gráfico 22

Participação dos repasses de instituições oficiais, no total do passivo circulante exigível, por instituição - BNDES

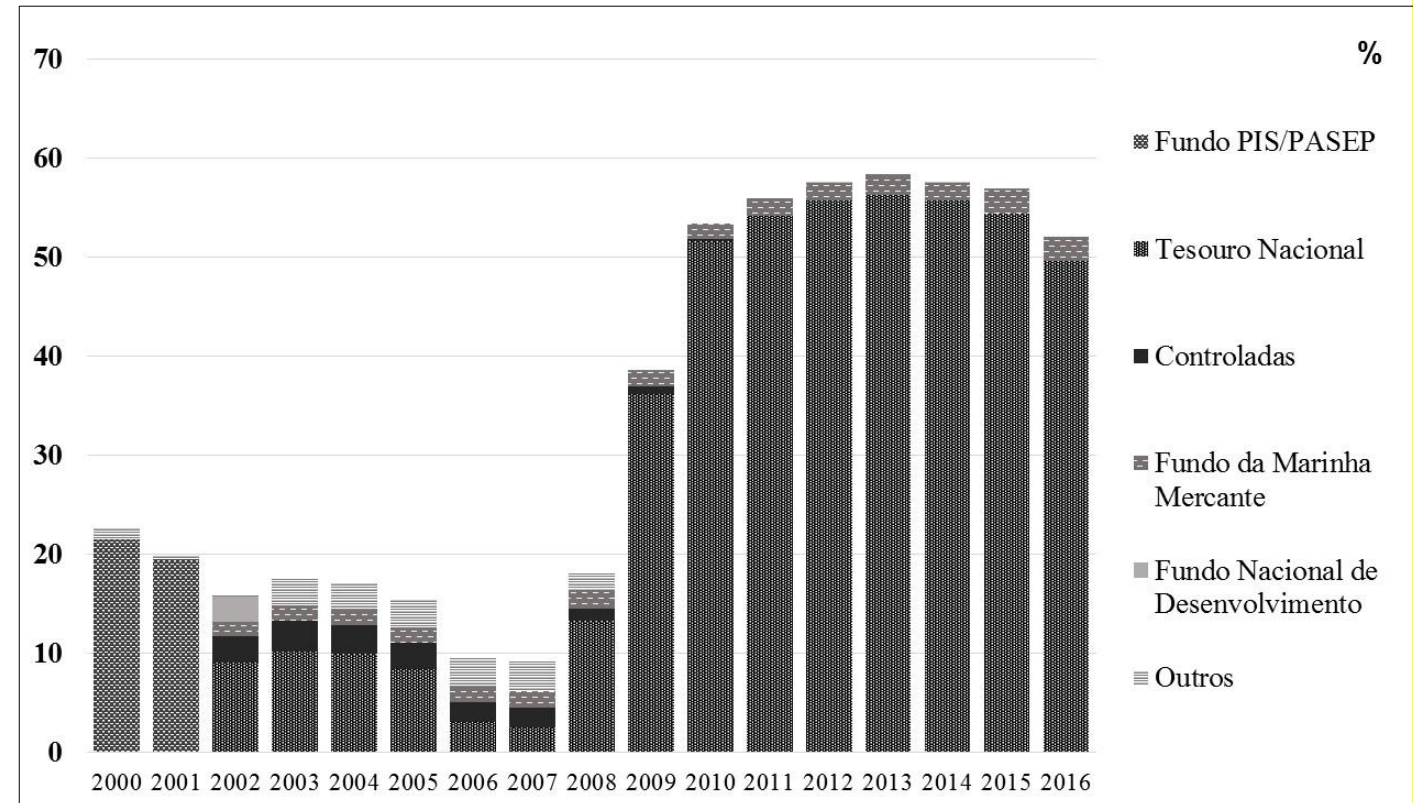

Fonte: Demonstrações Financeiras - BNDES (2000 até 2016).

A centralidade dos recursos do FAT, ainda que com participação declinante, e do Tesouro Nacional, em ascensão até 2015, na estrutura de recursos disponíveis ao BNDES, ressalta duas diferenças fundamentais, em comparação à Caixa e ao BB: a relativa concentração dos passivos, centralizados basicamente em duas contas, e a presença ainda mais significativa de recursos públicos, fiscais (aportes do Tesouro) e parafiscais (FAT e demais fundos), características pouco surpreendentes, em se tratando de um banco de desenvolvimento, ator central para políticas e programas governamentais, carente portanto de funding em condições especiais.

\section{Conclusão}

A análise da evolução dos balanços patrimoniais da Caixa, do Banco do Brasil e do BNDES, inclusive das informações constantes na série Balancetes, do BCB e de seus respectivos relatórios de administração, apresentam relevantes informações que contribuem para qualificar a discussão acerca da expansão das operações de crédito dos Bancos Públicos Federais, no período recente. 
Do ponto de vista das operações ativas, percebe-se que a expansão das operações de crédito foi acompanhada de relativa diversificação da atividade creditícia para as instituições com atividades comerciais. No caso da Caixa, em que pese a concentração das operações de crédito em empréstimos e financiamentos imobiliários, que continuaram exercendo protagonismo em sua atuação no mercado, verificou-se importante dinamismo nos financiamentos de desenvolvimento e infraestrutura. Para o BB, por seu turno, usualmente reconhecido por seu papel no financiamento rural e agroindustrial, a diversificação foi ainda mais acentuada, com participação crescente da modalidade empréstimos e títulos descontados, também conhecida como crédito livre, e com a entrada e rápida expansão desta instituição no mercado de crédito imobiliário. Ademais, é importante destacar que, para ambas as instituições, no auge da crise financeira internacional, o aumento da oferta de crédito, apesar de generalizado entre as várias modalidades, teve as taxas mais elevadas na modalidade dos empréstimos e títulos descontados. No caso do BNDES, sua especificidade enquanto banco de desenvolvimento implica em características distintas. Se, por um lado, há menor diversificação, com todas as operações concentradas numa única rubrica - financiamentos, isto é, crédito direcionado para o setor produtivo -, por outro lado, há importante variedade nas estratégias, com movimentos complementares entre as operações de primeiro piso e de segundo, a depender da conjuntura.

De modo semelhante, do ponto de vista das operações passivas, as instituições com atividades comerciais registraram significativa diversificação em suas fontes de recursos, com peso cada vez menor de tradicionais, como os depósitos, acompanhado de expansão de novas alternativas de financiamento. Para a Caixa, observa-se importante crescimento da participação dos recursos do FGTS no total do PCE, entre 2003 e 2015, movimento que seguramente contribuiu para a expansão dos financiamentos imobiliários e de desenvolvimento e infraestrutura. Além disso, esta instituição foi pioneira na utilização de fontes alternativas de financiamento, como os instrumentos híbridos de capital e dívida. No caso do BB, os repasses de instituições oficiais são menos relevantes, mesmo se forem consideradas também as operações relativas ao FAT, Funproger e FCO. A diversificação, neste banco, foi capitaneada pelo crescimento de outros instrumentos, sobretudo as Letras de Crédito do Agronegócio LCA.

Novamente, o movimento observado para o BNDES reflete seu caráter particular de instituição financeira de desenvolvimento, com pouca diversificação das fontes de recursos, que permaneceram concentradas em duas rubricas - outras obrigações, onde estão registrados os valores referentes ao FAT Constitucional, tradicional funding do BNDES; e obrigações por empréstimos e repasses, cujo crescimento acentuado, a partir de 2008 , responde aos diversos aportes do Tesouro Nacional, de magnitude superior a $\mathrm{R} \$ 416$ bilhões, que acrescidos dos juros e da correção perfizeram passivo da ordem de R 523 bilhões, em 2015. Esta relativa concentração se explica pelas próprias especificidades de sua atuação enquanto promotor do desenvolvimento, focado no crédito de longo prazo, o que implica na necessidade de condições especiais de funding. Ademais, as restrições de captação, em relação às possibilidades de bancos como Caixa e BB, interdita a obtenção de recursos por meio de fontes importantes para instituições financeiras comerciais, como os depósitos, por exemplo. 


\section{Referências bibliográficas}

ARAUJO, V.; CINTRA, M. O papel dos bancos públicos federais na economia brasileira. Brasília: Ipea, 2014. (Texto para Discussão, n. 1604).

ARAUJO, V.; PIRES, M. J. S.; SILVA, M. F.; CASTRO, D. A. O estado atual das instituições financeiras públicas para o desenvolvimento na América Latina: uma análise exploratória. Brasília: Ipea, 2011. (Texto para Discussão, n. 1616).

ARAUJO, Victor Leonardo. Preferência pela liquidez dos bancos públicos no ciclo de expansão do crédito no Brasil: 2003-2010. Brasília: Ipea, 2012. (Texto para Discussão, n. 1717).

BARBOSA, N.; SOUZA, J. A inflexão do governo Lula: política econômica, crescimento e distribuição de renda. In: SADER, E.; GARCIA, M. (Ed.). Brasil: entre o passado e o futuro. São Paulo: Fundação Perseu Abramo / Editora Boitempo, 2010.

BIELSCHOWSKY, R. Estratégia de desenvolvimento e as três frentes de expansão no Brasil: um desenho conceitual. Economia e Sociedade, v. 21, p. 729-747, 2012.

BRASIL. Banco Central do Brasil. Boletim do Banco Central do Brasil. Relatório 2008. Brasilia: BCB, 2009.

BRASIL. Banco Central do Brasil. Banco Central do Brasil, PROER - Programa de Estímulo à Reestruturação e ao Fortalecimento do Sistema Financeiro Nacional. 1999. Disponível em: http://www.bcb.gov.br/?RED1-PROER. Acesso em: 27 fev. 2015.

BRASIL. Banco Central do Brasil. Banco Central do Brasil, PROER - Programa de Estímulo à Reestruturação e ao Fortalecimento do Sistema Financeiro Nacional. 1999a. Disponível em: http://www.bcb.gov.br/?RED1-PROER. Acesso em: 25 jun. 2013.

BRASIL. Banco Central do Brasil. Plano Contábil das Instituições do Sistema Financeiro Nacional (COSIF). s. d. Disponível em: https://www3.bcb.gov.br/aplica/cosif.

BRASIL. Banco do Brasil. Banco do Brasil 200 anos. Belo Horizonte: Banco do Brasil, 2010.

BRASIL. Banco do Brasil. Relatório de Administração do Banco do Brasil. Brasília: BB, 2002 a 2016.

BRASIL. Banco Nacional de Desenvolvimento Econômico e Social. Demonstrações Financeiras. Rio de Janeiro: BNDES, 2002 a 2016.

BRASIL. Caixa Econômica Federal. Relatório de administração da Caixa Econômica Federal. Brasília: CEF, 2002 a 2015.

CAMARGO, P. O. A evolução recente do setor bancário no Brasil [online]. São Paulo: Unesp, 2009. SciELO Books: http://books.scielo.org>ed.

COSTA NETO, Y. C. Bancos oficiais no Brasil: origem e aspectos de seu desenvolvimento. Brasília: Banco Central do Brasil, 2004. 
COSTA, F. Ação anticíclica dos bancos públicos brasileiros. Brasília: Ipea, 2015. (Texto para Discussão, n. 258).

CUNHA, A. M.; CARVALHO, C.; PRATES, D. M. Estado atual do Sistema Nacional de Fomento e indicadores de desempenho. In: ABDE. Sistema Nacional de Fomento Financiando o Desenvolvimento. Rio de Janeiro: ABDE, 2014. p. 11-58.

FEIL, F. Comparação das políticas macroeconômicas e de transferência de renda e do papel do Estado dos governos Fernando Henrique Cardoso e Luis Inácio Lula da Silva. Porto Alegre: UFRGS, 2014.

FERRAZ, J. C.; ALÉM, A. C.; MADEIRA, R. A contribuição dos bancos de desenvolvimento para o financiamento de longo prazo. Revista BNDES, p. 5-42, 2013.

FREITAS, M. Dinâmica concorrencial e bancos públicos: questões conceituais. In: JAYME JR., F.; CROCCO, M. Bancos públicos e desenvolvimento. Rio de Janeiro: Ipea, 2010.

HERMANN, J. Bancos públicos em sistemas financeiros maduros: perspectivas teóricas e desafios para os países em desenvolvimento. In: ENCONTRO INTERNACIONAL DA ASSOCIAÇÃO KEYNESIANA BRASILEIRA (AKB), 2, set. 2009, p. 1-20.

HERMANN, J. Desenvolvimento financeiro e concorrência privada: desafios para a funcionalidade macroeconômica dos bancos públicos. In: JAYME JR., F.; CROCCO, M. Bancos públicos e desenvolvimento. Rio de Janeiro: Ipea, 2010. p. 233-257.

HORN, C.; FEIL, F.; TAVARES, D. Instituições financeiras de desenvolvimento no Brasil: razões e desafios para um Sistema Nacional de Fomento. Porto Alegre: UFRGS, 2015. Disponível em: http://www.ufrgs.br/ppge/pcientifica/2015_19.pdf.

JAYME JR., F. G.; CROCCO, M. Bancos públicos, federalismo e políticas de desenvolvimento regional no Brasil. In: JAYME JR., F.; CROCCO, M. Bancos públicos e desenvolvimento. Rio de Janeiro: Ipea, 2010. p. 179-204.

MORA, M. A evolução do crédito no Brasil entre 2003 e 2010. Rio de Janeiro: Ipea, 2015. (Texto para Discussão, n. 2022).

NOGUEIRA DA COSTA, F. Atuação anticíclica dos bancos públicos brasileiros. Campinas: Unicamp. IE, 2015. 28p. (Texto para Discussão, n. 258).

OLIVEIRA, G. C. Estrutura patrimonial do sistema bancário no Brasil no período recente (I2007/I-2014). Brasília: Ipea, 2015. (Texto para Discussão, n. 2162).

PRATES, D.; BIANCARELI, A. Panorama do ciclo de crédito recente: condicionantes e características gerais. [s.l.: snt., s.d.].

SALVIANO JR., C. Bancos estaduais: dos problemas crônicos ao Proes. Brasília: Banco Central do Brasil, 2004.

STUDART, R.; HERMANN, J. Estrutura e operação dos sistemas financeiros no Mercosul: perspectivas a partir das reformas institucionais dos anos 1990. Brasília: Cepal, 2001. (Texto para Discussão, n. 799). 


\section{Glossário}

Aplicações Interfinanceiras de Liquidez - Contas de aplicações em operações compromissadas, em depósitos interfinanceiros e em moedas estrangeiras

Créditos Vinculados - Juros e ajustes monetários referentes aos depósitos e outros recolhimentos

Depósitos - Integrado pelas contas de Depósitos à vista (conta corrente), Depósitos de poupança, Depósitos interfinanceiros, Depósitos sob aviso, Depósitos a prazo (Certificados de Depósitos Bancários e Recibos de Depósitos Bancários), Obrigações p/ depos. Espec. e de fundos e programas, Depósitos em moedas estrangeiras e Outros. No desagregado do Banco do Brasil, a rubrica Depósitos a prazo inclui também os Depósitos Judiciais, em Moeda nacional, em Moedas estrangeiras, Depósitos a prazo de reaplicação automática, Fundo de amparo ao Trabalhador (FAT), Funproger, Obrigações p/ depos. Espec. e de fundos e programas e Outros.

Disponibilidades - Rubrica de maior liquidez do ativo circulante, composta pelas contas caixa, reservas livres em espécie e aplicações em ouro.

Dívidas subordinadas - Contas de Recursos captados pelo Fundo Constitucional de Financiamento do Centro-Oeste (FCO), os CDBs Subordinados Emitidos no País, as dívidas subordinadas no Exterior e as Letras Financeiras Subordinadas.

Empréstimos - Operações sem destinação específica ou sem necessidade de vínculo de comprovação da aplicação dos seus recursos. Segundo a modalidade do Sistema de Informações de Crédito do Banco Central (SCR), os empréstimos abarcam as operações de crédito pessoal (com e sem consignação na folha de pagamento), crédito rotativo vinculado a cartão de crédito, adiantamento de receitas orçamentárias, cartão de crédito (compra, fatura parcelada ou saque financiado pela instituição emitente do cartão), home equity, microcrédito, cheque especial, conta garantida, capital de giro com prazo de vencimento de até 365 dias, recebíveis adquiridos, financiamento de projeto e outros empréstimos.

Financiamentos - Operações com destinação específica e com necessidade de vinculação à comprovação da aplicação dos recursos. De acordo com a modalidade do Sistema de Informações de Crédito do Banco Central (SCR), os financiamentos incorporam as rubricas de aquisição de bens (veículos automotores e outros bens), microcrédito, cartão de crédito (compra ou fatura parcelada pela instituição financeira emitente do cartão), recebíveis adquiridos, financiamento de projeto e outros financiamentos.

Financiamentos imobiliários - Financiamentos habitacionais do Sistema Financeiro da Habitação e de carteira hipotecária e financiamento de projetos e em empreendimentos imobiliários.

Financiamentos de infraestrutura e desenvolvimento - Operações especiais, para entes governamentais e privados, realizadas com recursos próprios, do SFH, do Sistema 
Financeiro de Saneamento, do Fundo de Financiamento para Saneamento e outros. Engloba os financiamentos de infraestrutura e desenvolvimento e de projetos.

Financiamentos de títulos e valores mobiliários - Rubricas de direitos por empréstimos e ações, carteira própria, carteira de terceiros, financiamentos de conta margem, financiamentos do PROCAP, direito por empréstimos de ouro e ajuste a valor de mercado para financiamentos de títulos e valores mobiliários objeto Hedge.

Financiamentos rurais e agroindustriais - Rubricas de custeio e pré-custeio, investimento e capital de giro de financiamento agroindustrial, comercialização e pré-comercialização e financiamento de projeto.

Fundo de Amparo ao Trabalhador (FAT) - Constitui-se como um fundo de natureza contábil e financeira, que opera concomitantemente em programas de geração de emprego e renda, inclusive no Programa de Geração de Emprego e Renda (Proger) e no Programa Nacional de Fortalecimento da Agricultura Familiar (Pronaf).

Fundo de Aval para Geração de Emprego e Renda (Funproger) - Fundo de natureza estritamente contábil, cuja função reside na concessão de aval para empreendedores que não possuem acesso ao financiamento do Proger Urbano e do PNMPO.

Instrumentos Financeiros Derivativos - Instrumentos cujo valor varia em decorrência de mudanças em taxa de juros, preço de título ou valor mobiliário, preço de mercadoria, taxa de câmbio, índice de bolsa de valores, índice de preço, índice ou classificação de crédito, ou qualquer outra variável similar específica, cujo investimento inicial seja inexistente ou pequeno em relação ao valor do contrato, e que sejam liquidados em data futura.

Instrumentos Híbridos de Capital e Dívida - Instrumentos de caráter perpétuo, estarem sujeitos aos pagamentos dos demais passivos da instituição emissora, além de não poderem ser resgatados por iniciativa própria do credor.

Obrigações por Empréstimos e Repasses - Incorpora os valores emprestados ou repassados a outras instituições, sendo classificados de acordo com a natureza da operação em Empréstimos no País - Instituições Oficiais, Empréstimos no País - Outras Instituições, Empréstimos no exterior, Repasses do País - Instituições Oficiais e Repasses do exterior. No BB, a rubrica incorpora o Tesouro Nacional, o BNDES, a Caixa, o Finame e Outras instituições. Na Caixaalém do BNDES, a rubrica incorpora o FGTS e Outras instituições.

Obrigações por Operações Compromissadas - Contas de Carteira própria, Carteira de terceiros e Carteira de livre movimentação.

Outras Obrigações - Contas de Cobrança e arrecadações de tributos e assemelhados, Carteira de câmbio, Sociais e estatutárias, Fiscais e previdenciárias, Negociação e intermediação de valores, Recursos para destinação específica, Obrigações Diversas e Diversas. No BB inclui Provisões técnicas de seguros, previdência e capitalização, Fundos financeiros e de desenvolvimento, Operações especiais, Dívidas subordinadas, Instrumentos 
híbridos de capital e dívida e Instrumentos de dívida elegíveis a capital. Na Caixa a rubrica inclui também Dívidas subordinadas (elegíveis e não elegíveis a capital), Instrumentos híbridos de capital e dívida e Instrumentos de dívida elegíveis a capital.

Operações de Arrendamento Mercantil - Inclui as contas de arrendamentos financeiros e operacionais a receber, subarrendamentos a receber, valores residuais a realizar, operações de arrendamento mercantil vinculadas e provisões para operações de arrendamento.

Operações de Crédito - O Banco Central faz a abertura dessa rubrica em três modalidades, sendo empréstimos, títulos descontados e financiamentos, ficando a cargo das próprias instituições financeiras a criação dos subtítulos internos que se fizerem necessário. (Cosif, p. 31). No balancete do Banco Central a abertura das operações de crédito inclui financiamentos rurais e agroindustriais, imobiliários, infraestrutura e desenvolvimento, títulos e valores mobiliários, operações de crédito vinculadas a cessões e provisão para operações de créditos (Balancetes, BCB). De acordo com a modalidade do Sistema de Informações de Crédito do Banco Central (SCR), as operações de crédito correspondem aos adiantamentos a depositantes, empréstimos e títulos descontados.

Outros Créditos - Abrange os subgrupos de Avais e Finanças Honrados, Câmbio, Rendas a Receber, Negociação e Intermediação de Valores, Créditos Específicos, Operações Especiais, Valores Específicos, Diversos e Provisões para Outros Créditos

Outros Valores e Bens - Inclui os subgrupos de participação societária, bens de uso próprio, material em estoque, valores em moedas estrangeiras, despesas antecipadas, mercadorias (conta própria) e provisão para desvalorização de outros valores e bens.

Permanente - Compreende as contas de investimentos, imobilizado (de uso e de arrendamento), diferido e intangível.

Recursos de aceites cambiais, letras imobiliárias e hipotecárias, debentures e similares No balancete do Banco Central, essa rubrica comporta as contas de Recursos de letras hipotecárias, Recursos de letras imobil, hipotec., de cred. e sim., Obrigações por títulos e valores mobiliários no exterior e Recursos de letras de crédito imobiliário.

Recursos para destinação específica - A conta é desdobrada em Obrigações de operações com loterias, Obrigações por fundos e programas sociais, Obrigações por fundos financeiros e de desenvolvimento e Obrigações por fundos e programas sociais.

Recursos de Aceites Cambiais - Ágios e deságios adquiridos por ocasião da colocação de letras de câmbio. 